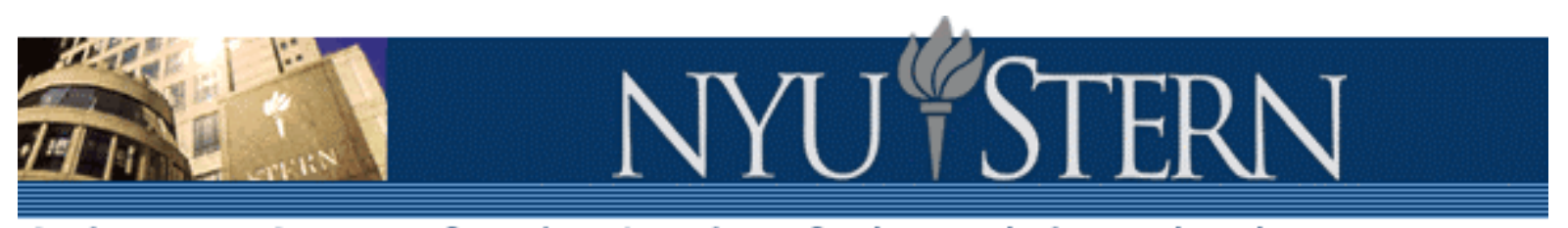

Salomon Center for the Study of Financial Institutions

Working Paper Series CREDIT \& DEBT MARKETS Research Group

THE IMPACT OF SHAREHOLDER CONTROL ON BONDHOLDERS

K.J. Martijn Cremers

Vinay B. Nair

Chenyang (Jason) Wei

S-CDM-04-06 


\section{The Impact of Shareholder Control on Bondholders}

\author{
K.J. Martijn Cremers \\ International Center for Finance \\ Yale School of Management
}

\author{
Vinay B. Nair \\ Stern School of Business \\ New York University
}

\author{
Chenyang (Jason) Wei \\ Stern School of Business \\ New York University
}

This version: March 2004*

\footnotetext{
*We would like to thank Kose John, Martin Gruber, Steve Kaplan, Andrew Metrick, Thomas Phillipon, Robert Whitelaw, Daniel Wolfenzon and participants of the Corporate Governance workshop at Stern School of Business for helpful comments. Nair gratefully acknowledges support from the Center of Law and Business at NYU.
} 


\title{
The Impact of Shareholder Control on Bondholders
}

\begin{abstract}
This paper investigates the effect of shareholder control on bondholder wealth. While stronger shareholder control can benefit bondholders by disciplining managers, it also increases the likelihood of events that can hurt bondholders, e.g. hostile takeovers. We hypothesize that shareholder control can have contrasting effects on bond yields depending on the takeover vulnerability of a firm. Using the presence of an institutional blockholder to proxy for shareholder control and firm-level anti-takeover provisions to proxy for takeover vulnerability, we find that shareholder control is associated with lower yields if the firm is protected from takeovers. We also find that shareholder control is associated with higher yields if the firm is exposed to takeovers. The contrasting effects of shareholder control on yields are the strongest for firms that are small and have low leverage. In the presence of shareholder control, the difference in bond yields due to differences in takeover vulnerability can be as high as 93 basis points. Further, the results are insignificant for a sub-sample of firms where the bondholders are protected from takeovers through the poison put covenant. Bond ratings also appear to incorporate a similar effect of shareholder control on bondholders Finally, we find that a bond pricing model that does not account for shareholder control generates an annualized abnormal return of $1 \%$ to $1.4 \%$ for portfolios that long firms with both strong shareholder control and high takeover vulnerability and short firms without either shareholder control or takeover vulnerability. Combined, these results suggest that the use of different governance mechanisms, such as shareholder monitoring and takeover vulnerability, depends on a firm's capital structure and that bond-pricing models should account for shareholder control.
\end{abstract}


"Generalized implications for creditors of companies that have controlling shareholders are not clear to us at this point. While there is substantial overlap between creditor and shareholder interests, there also are important potential conflicts."

- Moody’s ‘Rating Methodology' (2003)

\section{Introduction}

In their survey, Shleifer and Vishny (1997) broadly term corporate governance as 'the ways through which suppliers of capital to corporations assure themselves of getting a return on their investment'. The Anglo-Saxon view of corporate governance has mainly focused on transparency and strengthening shareholder rights; as witnessed by the recent governance reforms in the US and the UK. ${ }^{1}$ Since shareholders are, by virtue of their contract, the residual claimants of the firm cash flows, in this view higher shareholder vigilance automatically benefits bondholders - the other major supplier of capital - by reducing chances of bankruptcy due to managerial self-dealing. However, stronger shareholder control can also exacerbate the conflict between shareholders and other claimholders. This paper investigates the effect of stronger shareholder control on bondholders by not only considering the benefits but also potential costs and sheds light on the design of firm-level corporate governance.

Strengthening shareholders rights could hurt bondholders by increasing the likelihood of scenarios that benefit shareholders; some of which might entail losses for the bondholders. ${ }^{2}$ More specifically, if shareholder control results in an increase in leverage (as in Leveraged Buyouts), existing bondholders stand to lose. Higher leverage can reduce the value of outstanding bonds both by increasing the probability - and the deadweight costs - of a possible future bankruptcy and by reordering the priority of claims in bankruptcy. Even if a bond has priority covenants that prevent the firm from issuing bonds of equal or higher seniority, these priority rules are not completely upheld in the case of financial distress (see e.g. Franks and Torous (1989)). ${ }^{3}$ Therefore, an increase in leverage is likely to hurt bondholders unless the benefits of increasing leverage (e.g., reducing theft by reducing free cash flow (Jensen, 1990)) are large.

\footnotetext{
${ }^{1}$ See for example Black (1998), Coates et. al. (2002), Bebchuk (2004) and the Sarbanes-Oxley act of 2002.

${ }^{2}$ An alternative reason why bondholders might be hurt could be due to wealth transfer from bondholders to shareholders through asset substitution or risk shifting (Jensen and Meckling, 1976). We find weak evidence of this channel. See section 6 for a discussion.

${ }^{3}$ Weiss (1990) and Eberhart, Moore, and Roenfeldt (1990) present more evidence supporting violations of absolute priority rules.
} 
Important examples of events where shareholders might gain and bondholders might lose are acquisitions and disciplinary takeovers, especially since it has been shown that on an average leverage significantly increases after a takeover (Kim and McConnell, 1977, Cook and Martin, 1991, Ghosh and Jain, 2000). An extreme example of such an event is a Leveraged Buyout. Using trader quoted data, Warga and Welch (1993) show that bondholder losses range on average between 6-7\% on Leveraged Buyout announcements. $^{4,5}$

Since takeovers become more likely with stronger shareholder control (Shleifer and Vishny (1986)), a consequence of strengthening shareholder control and better aligning managers to shareholders could be to increase the likelihood of bondholder losses. ${ }^{6}$ As a result, stronger shareholder control can have both a beneficial (higher managerial discipline) and a detrimental effect (greater chances of leverage-increasing takeovers) on bondholders. Whether the net effect of stronger shareholder rights is beneficial or harmful depends on firm characteristics and is an empirical issue.

In this paper, we attempt to answer this question by first developing the hypothesis that firm-specific factors are likely to influence both benefits and costs of strong shareholder rights for bondholders, and then investigating how bond yields, ratings and returns vary with differing levels of shareholder control. We use a simple framework to capture both the positive and negative effects that shareholder control has on bondholder wealth to generate three specific hypotheses that we test. To proxy for strong shareholder control, we use the presence of an institutional blockholder (i.e., with equity ownership greater than 5\%). To proxy for a firm's exposure to the market for corporate control we consider charter-level takeover defense provisions.

Our main hypothesis is that shareholder control is beneficial for bondholders only when the firm is protected from takeovers. When the firm is exposed to takeovers, the benefits are offset by the now higher exposure to hostile takeovers. Thus the net effect of strong shareholder control is more likely to be harmful for bondholders of firms that are prone to takeovers. In addition to takeover protection, a larger firm size and higher

\footnotetext{
${ }^{4}$ They also show that bondholder losses only account for a small fraction of the shareholder gains.

5 In a more general setting of all mergers and acquisitions in the 80's and the 90's, Billet, King and Mauer (2003) consider the impact of takeovers on bondholder wealth. Although this study does not separate disciplinary takeovers from mergers and takeovers for managerial interests, it shows that when takeovers are accompanied by an increase in asset risk or reduction in credit rating of the target firm, the bondholders of the target firm lose.

6 Shleifer and Vishny (1986) argue that even if a firm is exposed to the market for corporate control, disciplinary takeovers are unlikely to occur if the shareholders are dispersed. Thus, a blockholder is essential, in addition to low takeover defense to make a firm truly vulnerable to takeovers.
} 
leverage (see e.g. Stulz, 1988, Harris and Raviv, 1988, Zweibel, 1997, and Novaes and Zingales, 1995) also reduces the takeover vulnerability of a firm and thus affects the impact of shareholder control on bondholders. Therefore, we also posit that shareholder control is more likely to be beneficial in firms that are large or/and have high leverage.

We find strong support for these hypotheses using bond yields of an average of 1839 issues per year from 1990 to 1997 . We find that shareholder control is associated with lower yields if the firm is protected from takeovers. We also find that shareholder control is associated with higher yields if the firm is exposed to takeovers. The contrasting effects of shareholder control on yields are the strongest for firms that are small and have low leverage. In the presence of shareholder control, the difference in bond yields due to differences in takeover vulnerability can be as high as 93 basis points.

We also provide strong evidence that this effect is important in bond pricing models. Specifically, we show that a portfolio that buys bonds of firms with strong shareholder control and high takeover vulnerability and shorts bonds of firms with neither high shareholder control nor takeover vulnerability generates an abnormal return of up to $1.3 \%$. This abnormal return is higher for firms that are small and have low leverage and can be as high as $2.5 \%$. Finally, bond ratings appear to incorporate a similar effect of shareholder control on bondholders.

To the best of our knowledge this is the first paper that shows that shareholder rights can have divergent and economically important effects on bondholders. In contrast to most of the literature investigating the effect of shareholder control and firm decisions on bondholders, we focus on yields, ratings and long run bond returns instead of analyzing bondholder wealth changes around certain events associated with bondholder losses, e.g. looking at spin-offs (Maxwell and Rao, 2003), takeovers and seasoned equity offerings.

In doing so, we also analyze how different governance mechanisms interact to affect bond returns, yields and ratings. This complements the study by Cremers and Nair (2003), which looks at the interaction of various governance mechanisms using equity prices and accounting cash flows. We also highlight the importance of using shareholder control in bond pricing models. To do so, we also apply the long run event study methodology used in Gompers, Ishii and Metrick (2003, henceforth GIM) and Cremers and Nair (2003) for equity prices to bonds. This approach, new in the literature on bondholder wealth effects, helps us understand how bondholders price in the effects of greater shareholder control and how these bond prices change over time. Finally, we shed light on the relative 
importance of risk-shifting and takeovers in the conflict between shareholders and bondholders. The results in this paper have important implications for bond rating agencies that, as the introductory quote suggests, are concerned but still debating how stronger governance affects bondholders.

Our work is related to Bhojraj and Sengupta (2003) and Klock, Mansi and Maxwell (2003) in their focus on the relation between bondholder wealth and corporate governance. However, important differences exist, as these papers exclusively analyze

how one single proxy for governance affect yields and/or ratings. Bhojraj and Sengupta (2003) use aggregate institutional ownership as their sole proxy for governance, and Klock, Mansi and Maxwell (2003) use the GIM-index and look at yields only. In addition, this paper also uses a portfolio approach and a time series of bond prices to see how the effects of governance evolve into bond returns. Second, consistent with a simple model that we present, the relation between governance and bondholder wealth is not uniform across all firms as in Bhojraj and Sengupta (2003) and Klock, Mansi and Maxwell (2003). In fact, we show it is critical to consider how the effects of corporate governance depend on size and leverage, resulting in e.g. opposite effects among small and large firms.

The rest of the paper is organized as follows. In the next section, we use a simple model to articulate our hypotheses. After describing the data in section 3, we tests our hypotheses using data on bond yields and credit ratings in section 4 . Section 5 investigates how bond prices change over time. In section 6, we discuss the possible interpretations of our results. Section 7 concludes.

\section{A Simple Model and Hypothesis}

We use a simple framework to develop our hypothesis. Consider two firms, identical in all respects except in the degree of shareholder control. We consider two extreme cases of strong shareholder governance and weak shareholder governance. In the first case, shareholders monitor the $\mathrm{CEO}$ at a cost $\mathrm{C}$ while in the latter case the CEO is not monitored. For simplicity, we call the firm with strong shareholder control Watchdog Inc. and the firm with weak shareholder control Lapdog Inc. Both firms have a self-interested CEO and a single profitable project. The project has two possible payoffs - a high cash flow $(\mathrm{H})$ or a low cash flow $(\mathrm{L})$ with probability $\mathrm{p}$ and 1-p respectively. If not monitored, the CEO expropriates amount, $\mathrm{S}(<\mathrm{L}<\mathrm{H})$, from the cashflow of the firm in both possible 
scenarios. Therefore, the manager is unable to steal in Watchdog Inc and that the manager steals $\mathrm{S}$ in Lapdog Inc.

The time line is shown in Figure 1. The project is taken at time 0 with funds raised through the issuance of stock and bonds and the cashflows are realized at time 2. Assume that the firm issues bonds of face value $\mathrm{F}$ and funds the remaining investment through stocks. To focus on the interesting case I assume that

\section{A.1 $\mathrm{L}-\mathrm{S}<\mathrm{F}<\mathrm{L}<\mathrm{H}-\mathrm{S}$}

\section{A.2 $\mathrm{C}<\mathrm{pS}$}

The first assumption ensures that bankruptcy occurs in the low state due to expropriation while the second assumption ensures that it is in the interests of shareholder to monitor the CEO.

At time 1, a bidder appears with probability t. Assume that the bidder is honest and hence under the bidder's management there is no theft. ${ }^{7}$ As argued earlier, bondholders face significant wealth changes during takeovers. Evidence on disciplinary takeovers suggests that bondholder wealth changes are negative (Warga and Welch, 1993). ${ }^{8}$ To capture this in reduced form, we simply assume that bondholders lose value $\mathrm{W}$ from a successful takeover. ${ }^{9}$ Clearly, if $\mathrm{W}$ is negative, then bondholders will gain and our hypothesis will change accordingly.

Let us now proceed to derive the bond prices for the firm with no shareholder control (Lapdog Inc.) and the firm with strong shareholder control (Watchdog Inc.). In the absence of any shareholder control, it is clear that the CEO will not be a willing target since he loses the opportunity to expropriate S. Therefore in the absence of any shareholder control, Lapdog Inc. will not be taken over at time 1 and the CEO will steal amount $\mathrm{S}$ at time 2, leaving the external claimholders $\mathrm{H}-\mathrm{S}$ in the high state and L-S in the low state. The price of bond will then be

$$
\mathrm{P}(\text { Lapdog Inc. })=\mathrm{pF}+(1-\mathrm{p})(\mathrm{L}-\mathrm{S})=\mathrm{F}-(1-\mathrm{p})(\mathrm{F}-\mathrm{L}+\mathrm{S})=\mathrm{F}-(1-\mathrm{p}) \Delta
$$

\footnotetext{
${ }^{7}$ This ensures that there is some value creation due to the takeover.

${ }^{8}$ Even if the takeover mechanism is not a LBO, evidence suggests that the leverage of a firm goes up due to takeovers. As argued earlier, this is likely to hurt bondholders.

${ }^{9}$ These could be losses due to an increase in leverage, or other sources such as an increased likelihood of asset sales, spinoffs etc.
} 
where $\Delta=$ F-L + S. ${ }^{10}$

In the presence of a large monitoring shareholder, the bidder is more likely to succeed. The shareholders can tender their shares and save themselves the cost of monitoring C. ${ }^{11}$ Assuming that shareholders of Watchdog Inc. tender their shares in all cases of an offer, the probability of the firm being taken over at time 1 is then simply the probability of the bidder appearing which is t. ${ }^{12}$ If the bidder does not appear, the shareholders continue monitoring the manager and prevent managerial theft. The price of the bond in this case is

$$
\mathrm{P}(\text { Watchdog })=\mathrm{t}(\mathrm{P}(\text { Watchdog })-\mathrm{W})+(1-\mathrm{t})(\mathrm{pF}+(1-\mathrm{p}) \mathrm{F})
$$

Note that the expected value of the bond in case of a takeover (the first term in the expression above) captures the loss of $\mathrm{W}$. Rearranging, the price of the bond is given by

$$
\mathrm{P}(\mathrm{Watchdog})=\mathrm{F}-\mathrm{Wt} /(1-\mathrm{t})
$$

The condition for the $\mathrm{P}($ Watchdog $)$ to be greater than $\mathrm{P}(\mathrm{Lapdog})$ is summarized by the following proposition.

Proposition 1: In the presence of shareholder control, the price (yield) of the bond falls (rises) when

$$
\mathrm{W} \mathbf{t} /(1-\mathbf{t})>(1-p) \Delta
$$

\section{where $\Delta=\mathbf{F}-\mathbf{L}+\mathbf{S}$.}

The condition above gives us our main hypothesis; that stronger shareholder control will be associated with higher (lower) bond yields when the firm is (not) vulnerable to takeovers.

Since the probability of a takeover is a function of firm size, leverage (Stulz, 1988, Harris and Raviv, 1988, Zweibel, 1997, Novaes and Zingales, 1995) and the level of

\footnotetext{
${ }^{10}$ For simplicity, in the theoretical development of the hypothesis, we consider the case of risk neutral bondholders and a risk free rate of 0 .

${ }^{11}$ The value to the bidder is $\mathrm{p}(\mathrm{H}-\mathrm{F})$. The value to the target shareholders is $\mathrm{p}(\mathrm{H}-\mathrm{F})-\mathrm{C}(>\mathrm{p}(\mathrm{H}-\mathrm{D}-\mathrm{S}))$. Therefore there is a value creation opportunity of amount $\mathrm{C}$ that will be shared between the bidder and the target shareholders, based on their relative bargaining powers.

${ }^{12}$ All that is required is that the probability of a takeover increase with greater shareholder control.
} 
takeover defense provisions we rewrite the proposition above into the following hypotheses.

H1. Stronger shareholder control will be associated with higher (lower) bond yields when takeover defenses are lower (higher).

H2. Stronger shareholder control will be associated with higher (lower) bond yields when takeover defenses are lower (higher) and the firm is smaller (bigger).

A lower leverage (lower F) not only increases the likelihood of a bidder appearing ( $t$ ) but also affects $\Delta$. A lower leverage reduces the left hand side and increases the right hand side of the condition above. Further, if bondholder wealth losses are because of an increase in leverage, such losses are more likely when the target firm has relatively low leverage. Thus the interaction of shareholder control and leverage is unambiguous and is stated in the hypothesis below.

H3. Stronger shareholder control will be associated with higher (lower) bond yields when takeover defenses are lower (higher) and leverage is lower (higher).

In the following, we test these three hypotheses using yields and also analyze how bond prices changes over time. We start with the description of our data.

\section{Data}

The data used in this study can be separated into three categories - A) data on corporate bonds, B) data on governance mechanisms and C) data on firm characteristics.

\section{A. Corporate Bonds}

We use two sources to collect the information required on corporate bonds. We use the Lehman Brothers' Bond Database (LBBD) to construct yield spreads of bonds (used in section 4). The Lehman Brothers' Bond Database (LBBD) reports the institutional pricing for Treasury and corporate bonds over the 1973 - 1997 time period. As our firmspecific corporate governance proxies only start in 1990, we use only the latter part of the 
database. Our sample includes an average of 1,839 corporate bonds per year from 1990 to 1997. On average, there are 4.3 corporate bonds with the same issuing firms in our sample. LBBD contains both matrix prices as well as dealer quotes, where matrix prices are set according to some pricing algorithm based on bonds with similar characteristics. As matrix prices are regarded as less reliable than actual dealer quotes (see e.g. Warga and Welch (1993)), we only use dealer quotes. Finally, LBBD also provides information on some issue-level control variables such as issue size, number of years to maturity, dummies for callability, senior and senior-secured debt, and for 7 rating categories (for details, see the description of Table 3).

The risk-free term structure of interest rates are from Salomon Brothers Yield Book, including the monthly treasury benchmark yields with time-to-maturity of 1 year, 2 years, 3 years, 5 years, 10 years, 20 years and 30 years are retrieved.. The term structure of interest rate is used not only to compute yield spreads but also abnormal bond returns (used in section 5).

We also use the Fixed Income Securities Database (FISD) to obtain information on bond covenants that protect bond investors. FISD contains detailed issue-level information on over 140,000 corporate, US Agency, US Treasury and supranational debt securities. Specifically, we focus on one critical covenant provision related to takeovers, namely the existence of a 'poison put'. A poison put covenant gives bondholders the option of selling the issue back to the issuer at par or at a premium upon a change of control in the issuer. Poison puts are often used when a company fears an unwanted takeover (see Datta (1996) and Asquith and Wizman (1990)).

\section{B. Governance Mechanisms}

Our proxy for whether or not there is shareholder control is a dummy for the existence of an institutional blockholder, denoted by BLOCK = 1 if such an institutional blockholder is present. We define blockholders as shareholders with an ownership greater than $5 \%$ of the firm's outstanding shares. To construct this measure, we use data on institutional share holdings from Thompson / CDA Spectrum, which collects quarterly information from the SEC $13 \mathrm{f}$ filings. ${ }^{13,14}$ By using institutional blockholding rather than

\footnotetext{
${ }^{13}$ The 1978 amendment to the Security and Exchange Act of 1934 requires all institutional investors with more than $\$ 100$ million under management to report their shareholdings to the SEC.
} 
simply institutional ownership, we mitigate the problem that institutions with minor stakes have few incentives to be involved in firm-specific decisions. Furthermore, Shleifer and Vishny (1986) argue that blockholders often have substantial voting control, enabling them to pressurize the firm's management.

We use data on anti-takeover provisions in the firm's charter from Investor Research Responsibility Center (IRRC) publications to construct an anti-takeover index (ATI) that proxies an individual firm's exposure to the market of corporate control. We also confirm our results using the index developed, from the same source, by Gompers, Ishi and Metrick (2003). The IRRC data used to construct these indices are available during our time period for the years 1990, 1993 and 1995. While IRRC does not update all companies in a new edition, Gompers, Ishi and Metrick (2003) argue that there is no reason to suspect systematic biases in this data.

ATI (for a detailed description, see Cremers and Nair (2003)) uses information on three anti-takeover provisions that the literature has recognized to be the critical for takeovers - preferred blank check, staggered boards and restrictions on calling special meetings and action through written consent. The existence of the preferred blank check not only implicitly equips the firm with a poison pill, but also enables the management to issue new classes of stock without shareholder approval and significantly reduces takeover probability (see e.g. Ambrose and Megginson (1992)). Further, classified boards as well as restrictions on calling specials meetings and action through written consent create significant delays in takeover battles (see e.g. Benchuk, Coates, and Subramanian (2002) and Daines and Klausner (2001)). ${ }^{15}$ Therefore, these provisions create barriers to takeovers in addition to the poison pill (blank check). In fact, some legal scholars deem classified boards the single most important factor in takeover defense due to the long delay it causes. ${ }^{16}$

These three provisions produce a takeover vulnerability index varying from 0 to 3 , adding one point if a provision is not in place. We classify firms with ATI $=0$ as having lowest takeover vulnerability, and those with ATI $=3$ as being most prone to takeovers.

\footnotetext{
${ }^{14}$ Non-institutional blockholders are omitted in the study, due to the difficulty of collecting reliable data for such a large sample over this time period. We will discuss to extent to which this omission may affect our results.

${ }^{15}$ Daines and Klausner (2002) show that restrictions on calling special meetings coupled with restrictions on acting through written consent can delay the acquiror by 12 to 18 months, depending on state laws.

${ }^{16}$ Bebchuk et al. (2002) find that an effective staggered board doubled the odds of remaining independent for an average target. A classified board can impose a delay of up to 2 years.
} 
In any year, about $31 \%$ of firms have ATI $=0,32 \%$ have ATI $=1,32 \%$ have ATI $=2$, and finally about $5 \%$ of firms have ATI $=3$.

The index based on Gompers, Ishi and Metrick (2003) is termed EXT. The index EXT incorporates 24 different provisions in 5 categories - tactics for delaying hostile bidders, voting rights, director/officer protection, other takeover defenses and state laws all of which directly affect takeover protection. ${ }^{17}$ The index EXT is formed by adding one point if the firm does not have a specific defensive provision in place and zero otherwise, leading to values between 0 and 24. As a result, a larger value of EXT signifies fewer protections against the market for corporate control, and thus greater exposure to takeovers. $^{18}$

\section{Firm Characteristics}

Firm characteristics such as leverage and market capitalization, are obtained from the Compustat / CRSP database. Firm accounting data are from the Compustat Quarterly database. All variables are lagged by 3 months to ensure that the accounting information is public when rating/yield analysis is conducted. Leverage is defined as (Total long-term debt + Debt in current liabilities)/Total liabilities.

\section{Shareholder Control, Bond Spreads and Ratings}

In this section, we document the impact of shareholder control on corporate bond spreads, and test the hypotheses stated in section 2. The bond spreads are bond yields adjusted for the risk-free term structure of interest rates. For each issue, we match by time-to-maturity to get the corresponding Treasury benchmark yield. Monthly treasury benchmark yields with time-to-maturity of 1 year, 2 years, 3 years, 5 years, 10 years, 20 years and 30 years are retrieved from Salomon Brothers Yield Book. We use linear interpolation to calculate treasury yields with time-to-maturity of other years below 30 . For the few observations with time-to-maturity above 30 years, we use the 30-year treasury benchmark. For each observation, the spread is calculated as the difference between the bond yield and its corresponding treasury benchmark.

\footnotetext{
${ }^{17}$ For a more detailed description of the 24 provisions, see Gompers, Ishi and Metrick (2003).

${ }^{18}$ Therefore, our external governance index is a linear transformation of the index as used in Gompers, Ishi and Metrick (2003), which is denoted by G, such that EXT $=24-\mathrm{G}$.
} 
We start by presenting some summary statistics of our data. Table 1 reports the average number of bonds per year and per firm, the quartile percentages of the shareholdings of the largest blockholder and of the shareholders rights index EXT as well as the number of firms in the four ATI groups are given. Our sample consists of an average of 1839 bonds from 426 firms per year, or 4.3 bonds per firm. ${ }^{19}$ The takeover vulnerability indices ATI and EXT are fairly stable over time for most firms. About a quarter of firms have EXT $\leq 12$ and a quarter of firms have EXT $\geq 16$. The distribution of ATI is more lopsided, with about $32 \%$ of the firms having no takeover protection $(\mathrm{ATI}=0)$ and $5 \%$ of the firms protected completely $(\mathrm{ATI}=3)$. Around $63 \%$ of firms have a blockholder at any one time and consistent with the evidence on increasing institutional ownership in the 90s (Gompers and Metrick, 1999), blockholder ownership appears to have increased over this time period.

Table 2 reports the correlation matrix of EXT, BLOCK, SIZE, LEVERAGE and RATING. Most correlations are relatively small, the exceptions being that RATING has a $56 \%$ correlation with SIZE and a $-26 \%$ correlation with the industry-adjusted LEVERAGE, where RATING is defined such that a higher value implies a lower probability of bankruptcy. Also, EXT and BLOCK have a low, negative correlation of $6 \%$, and are uncorrelated with SIZE.

In table 3 (4), we report the results from the panel regression of corporate bond spreads on the various governance-related variables plus the firm-specific control variables using ATI (EXT) as the proxy for exposure to takeovers. We report the basic results in panel $\mathrm{A}$, and those that include fixed issuer effects in panel $\mathrm{B} .{ }^{20} \mathrm{We}$ discuss the results without fixed issuer effects first.

\section{A.1. The Impact of BLOCK on Bond Spreads (using ATI)}

Before we begin to test our hypotheses, we look at the effect of shareholder control (BLOCK) and exposure to takeovers (ATI and ATI*BLOCK) independently in the first three models. The interaction term, ATI*BLOCK, is intended to capture 'effective' takeover vulnerability since the presence of a blockholder might be necessary to facilitate

\footnotetext{
${ }^{19}$ That means that the reported t-statistics need to be interpreted with some caution. In case of perfect correlation across different issues per firm, for all firms, the t-statistics would need to be divided by the square root of 4.3, i.e. 2.07. However, even if this extreme case basically all our main results hold.

${ }^{20}$ Fixed issuer effects are incorporated using dummies for each issuer (the coefficients are not reported).
} 
takeovers even if the firm does not have takeover protection. ${ }^{21}$ Thus, a blockholder in addition to low takeover defenses is essential to make a firm truly vulnerable to takeovers.

Each of the first three models has one variable; namely BLOCK, ATI and ATI*BLOCK, in addition to the set of controls. First, we find that shareholder control by itself, as proxied by BLOCK, is not significantly related to bond spreads. A possible reason for this, which we confirm below, is that BLOCK has opposite effects depending on whether the firm is prone to takeovers or not. This view is further strengthened by observing that both ATI and ATI*BLOCK by themselves have positive and significant coefficients, indicating that increased exposure to the market for corporate control increases bond spreads.

We test our main hypothesis $\mathrm{H} 1$ in model 4 where we consider all three variables (ATI, BLOCK and ATI*BLOCK) simultaneously in addition to the set of controls. As per our hypothesis, we would expect yields to reduce with BLOCK but increase with BLOCK*ATI. Indeed and consistent with our hypothesis, BLOCK now has a strongly negative and significant coefficient, equal to -0.24 with a t-stat of -7.2 , and ATI*BLOCK has a strongly positive and significant coefficient, equal to 0.12 with a tstat of 8.3. The coefficient of ATI is insignificant. This corroborates the complementary relationship of firms' takeover provisions and the existence of active shareholders established in Cremers and Nair (2003) and suggests that exposure to takeovers is a concern to bondholders only in the presence on large shareholders.

Therefore, BLOCK appears to be associated with two opposite effects. First, the existence of an active shareholder can facilitate the transfer of control for firms whose provisions do not preclude takeovers. This makes such firms more vulnerable for leverage-increasing takeovers, hence bond issued by these firms demand higher yields. Second, higher shareholder vigilance, in this case by large institutional shareholders, could reduce the chance of bankruptcy and decrease yields. This confirms our hypothesis H1. Also, note that the observed effects are economically important. A firm with both active shareholders (i.e. BLOCK equal to one) and few anti-takeover provisions $(\mathrm{ATI}=3)$ is associated with a yield spread of 12 basis points higher $(-24+3 \times 12)$ than firms without a blockholder. A firm with a blockholder but takeover protection (ATI $=0$ ) is associated with a yield spread of 24 basis points lower than a firm without a

\footnotetext{
${ }^{21}$ Shleifer and Vishny (1986) argue that even if a firm is exposed to the market for corporate control, disciplinary takeovers are unlikely to occur if the shareholders are dispersed.
} 
blockholder. Thus, contingent on the exposure to takeovers, blockholders are associated with contrasting effects on yield spreads, with the difference between ATI $=3$ and $\mathrm{ATI}=0$ being 36 basis points $(24-(-12) \mathrm{bp})$.

Next, we proceed to consider hypotheses $\mathrm{H} 2$ and $\mathrm{H} 3$ by investigating the impact of size and leverage due to their impact on takeover vulnerability. 'Effective' takeover vulnerability now includes the presence of a blockholder, low takeover defense, a lower size and lower leverage. We sort all firms independently into 3 different groups according to both size (small-medium-large) and leverage (low-medium-high), and create dummies for small and large size as well as low and high leverage. The dummy coefficients should be interpreted relative to the associated medium categories. Here, size is measured as the market capitalization of the outstanding equity, and for leverage we use industry-medianadjusted leverage. The 48 Fama-French (1997) industry classifications are used for industry-adjustments through out the paper.

In model 5, we add the interaction of ATI*BLOCK with the small and large size dummies to the variables in model 4 . The results strongly confirm our hypothesis $2(\mathrm{H} 2)$, that stronger shareholder control increases yields for small firms, as the coefficient for ATI*BLOCK of small firms is a highly significant 0.23 whereas the coefficient for large firms is negative but insignificant (-0.01), which constitutes a clearly statistically significant difference. Therefore, a firm with a blockholder and exposure to takeovers $(\mathrm{ATI}=3)$ is associated a yield spread of 36 basis points higher than a firm with blockholders and protection from takeovers $(\mathrm{ATI}=0)$ if the firm is small.

We now proceed to investigate the effect of leverage. We find that conditioning on leverage alone leads to no differences in the effect of shareholder control. Specifically, when we add low and high leverage dummies to the interaction of ATI*BLOCK (model 6), we observe no differences. However, when we interact the complementary measure of takeover vulnerability, ATI*BLOCK, with both the small and large size dummies as well as the low and high leverage dummies simultaneously (model 7), the evidence is supportive of H3. For the large firms, the coefficients on ATI*BLOCK is similar (and not statistically different) for high and low leverage firms. However, for the small firms, the coefficient on ATI*BLOCK is lower for firms with higher leverage (a difference of 3 basis points), and that difference is (marginally) significant. The evidence supports hypothesis 3 (H3), that shareholder control is associated with higher yields for firms that 
have lower leverage. However, the hypothesis is supported only for those firms that are small.

\section{A.2. With Fixed Issuer Effects}

The corresponding results using ATI that include fixed issuer effects, as found in panel $\mathrm{B}$ of table 3, confirm the main results above. An encouraging sign is that the impact of size and leverage with respect to the coefficient of ATI*BLOCK are stronger with fixed issuer effects. Specifically, the (cumulative) coefficient on ATI*BLOCK is -0.05 for large firms with high leverage, 0.07 for large firms with low leverage, 0.17 for small firms with high leverage, 0.31 for small firms with low leverage, compared to an average coefficient of 0.12. Most importantly, all coefficients and all differences between coefficients are statistically significant, confirming all our hypotheses. The appearance of a blockholder is now associated with an increase of $78(=93-15)$ basis points if the firm is exposed to takeovers (ATI = 3), has low leverage and is small in size and a zero cumulative effect $(=5 \times 3-15)$ firm is large and has high leverage. On the other hand, the appearance of a blockholder is associated with a decrease of 15 basis points if the firm is not exposed to takeovers $(\mathrm{ATI}=0)$.

\section{A.3 Using EXT as a Proxy For Takeover Protection}

A final robustness check is done using EXT rather than ATI as the measure of the number of provisions related to takeovers. The results without fixed issuer effects are presented in Table $4 .{ }^{22}$ The results are statistically similar to those using ATI.

In order to compare the economic significance of both sets of results, we can multiply all coefficients for EXT by 3, which is the ratio of the respective standard deviations of EXT and ATI (which are equal to 2.71 and 0.90, respectively). That way, the re-scaled coefficient of EXT*BLOCK in model 4 equals 0.07 , which is only about half the impact of ATI, which has a corresponding coefficient of 0.12 . As a further example we take the difference in the re-scaled coefficients of EXT*BLOCK with respect to size, which produces a 5 basis point difference in for small relative to large firms. In contrast, there is a 12 basis point greater impact for an increase in ATI for small

\footnotetext{
${ }^{22}$ The coefficients on the control variables are omitted in the interest of exposition and are similar to the ones reported in Table 3 .
} 
as compared to large firms. Finally, the results using EXT with fixed issuer effects are similar to those without fixed effects and are not presented in the interests of space.

It is useful to discuss the results in Klock, Mansi and Maxwell (2003) in order to highlight the contrasting effects of shareholder control. Klock et. al. focus on the direct relationship between bond yields and the Gompers, Ishii and Metrick (2003) index (EXT). In effect, their paper exclusively investigates model 2 in Table 4 in our paper, and does not account for the interaction of EXT with the presence of active shareholders (BLOCK) nor explores the effects of size and leverage on this interaction. As regression models 4 - 7 indicate, the interaction between shareholder control and takeover protection is important and varies across firms.

Our results confirm the complementary relationship between active shareholders and direct exposure to the market of corporate control, as documented in Cremers and Nair (2003) for equity prices. Specifically, the coefficient of EXT in model 4 is -0.004 with a t-stat of -1.03 , while the coefficient of EXT*BLOCK is 0.023 with a t-stat of 4.71 . Therefore, the increase of bond spreads associated with fewer anti-takeover provisions is only existent for firms where there is an active shareholder as well. Furthermore, accounting for BLOCK also greatly increases the economic impact of a one-point increase in EXT, comparing a coefficient of EXT in model 2 equal to 0.009 to a coefficient of EXT*BLOCK in model 4 equal to 0.023.

\section{B. Shareholder control and ratings}

In this section, we digress briefly to see the marginal effects of shareholder control and takeover vulnerability on the likelihood that a firm falls in a particular S\&P rating category. The main motive for doing so is to see whether the rating agencies implicitly or explicitly capture these governance relations. If they do, our results would be economically stronger since we already control for ratings. If the rating agencies capture these governance mechanisms in a direction opposite to what the yield spread results then our results might be weaker as the net economic importance might now be lower.

An ordered probit model is used to relate the different rating categories to the governance and control variables (see Blume, Lim and MacKinlay (1998) and Bhojraj and Sengupta (2003) for other papers using an ordered probit for this purpose). Following Fama and French (2001), we first estimate the probit regressions across firms for each 
quarter separately and then, in the spirit of Fama and MacBeth (1973), report the time series averages of the coefficients. This allows for correlation of the regression residuals across firms. We define a seven-way classification representing S\&P ratings (closest to) AAA, AA, BBB, BB, B, CCC, and lower, respectively. The model is set up such that it is modeling the probability of the highest rating level. Finally, the models are exactly analogous to those used for the bond-spread regressions in the previous section to facilitate a direct comparison.

\section{Basic results using ATI}

First, the marginal effects of BLOCK, ATI and ATI*BLOCK individually are considered in the first three models, and all three are combined in model 4 . We find that the existence of an institutional blockholder, as a proxy for an active shareholder, strongly decreases ratings by itself. This is evidenced by a coefficient of BLOCK equal to -0.48 (t-stat of -18.4) in model 1, confirming one of the main results in Bhojraj and Sengupta (2003). However, we will later see that the negative impact on ratings is mostly due to the interaction of BLOCK with ATI, and not of BLOCK by itself.

Most interesting, ATI by itself in model 2 has a positive and significant coefficient of 0.10 (t-stat of 10.1). This separate effect of ATI is clearly stronger and much more robust than the corresponding effect in the spread regressions, where the effect of ATI by itself is only very marginally significant for fixed issuer effects and disappears when ATI*BLOCK is included as well. This is the first paper documenting the effect of takeover vulnerability on ratings, and our results suggests that the rating agencies indeed take takeover protection provisions into account.

Interestingly, we also find that ratings react to the interaction of BLOCK and ATI in the same direction as yield spreads do. ATI*BLOCK by itself in model 3 has a negative and significant coefficient of -0.15 (t-stat of -12.9 ). Combining BLOCK, ATI and ATI*BLOCK all three in model 4 increases the economic significance of ATI (coefficient of 0.20 with t-stat of 11.0) as well as the complementary interaction of ATI with BLOCK (coefficient of -0.18 with $\mathrm{t}$-stat of -6.9 ). Thus, the net effect of a high takeover vulnerability and high shareholder control is higher than what the yield-spread regressions suggest. 
In contrast with the spread regressions where BLOCK was found to have opposite effects depending on whether a firm is prone to takeovers or not, ${ }^{23}$ here BLOCK's coefficient is consistently negative though hardly significant. ${ }^{24} \mathrm{Next}$, the effect of size on the impact of takeover vulnerability as measured by ATI*BLOCK appears to be particularly significant for ratings. In model 5, a greater takeover vulnerability even has increases the rating for the largest third of firms, as evidenced by an overall positive marginal effect. In sharp contrast, the marginal effect for the smallest third of firms is strongly negative or decreasing ratings.

In order to interpret the economic significance of the coefficients of ATI*BLOCK for bond of firms of different sizes, we calculate the marginal effect of an increase of those coefficients from their median coefficient by one unit. For bonds with an average rating of A-, the model probability of being in that rating category decreases by $21.6 \%$ for small firms, increases by $0.6 \%$ for large firms, and decreases by $5.9 \%$ on average.

Relative to the size effect, the role of leverage is limited. Leverage by itself has no discernable impact on the coefficient of ATI*BLOCK (see model 6), and only a small effect once combined with size in model 7. There is some evidence that the negative marginal effect of $\mathrm{ATI}^{*} \mathrm{BLOCK}$ is strongest for not just small firms, but more specifically small firms with higher leverage than average. However, this difference is not economically significant. Specifically, for averaged rated bonds, a unit increase in the coefficient of $\mathrm{ATI}^{*} \mathrm{BLOCK}$ decreases the probability of being in the average rating category decreases by $21.8 \%$ for small firms with high leverage and by $18.4 \%$ for small firms with low leverage. Furthermore, this effect does not appear to be particularly robust, as there is hardly any difference between ATI*BLOCK's coefficient for low and high levered small firms when using EXT. The results using EXT are similar to the results using ATI and are presented in Table 6.

These results show that the rating agencies view shareholder control beneficial for firms that are large and protected from takeovers and harmful for firms that are exposed to takeovers and are small. Even after controlling for this effect of shareholder control on ratings, yield spreads further reflect the effects of shareholder control - perhaps due to the delayed updating of ratings. For the variables that rarely change over time, e.g.,

\footnotetext{
${ }^{23}$ However, this result became marginally significant for ATI and disappeared for EXT for fixed issuereffects.

${ }^{24}$ Note that the t-stats have to be divided by approximately 2 to control for the average number of 4.3 bond issues per firm.
} 
ATI/EXT, the ratings capture all the effect leaving no residual effects for the yield spreads, lending support to the view that delayed updating might be important.

\section{Bond Returns}

We have shown that bondholders demand a significantly higher yield for bonds of firms that have both a large shareholder and low takeover defense. In this section, we investigate the extent to which realized bond returns reflect these expectations by comparing the returns of a portfolio of firms that have both a large shareholder and high takeover vulnerability to a portfolio of firms with neither a large blockholder nor a high vulnerability to takeovers.

To account for systematic differences in the portfolios, we use a we use the Elton, Gruber and Blake (1995) four-factor model: including an equity market factor (S\&P 500 excess returns), a corporate bond market factor (Salomon Brothers (SB) corporate bond index excess returns), a default risk factor (the difference between returns from the SB High Yield bond market index and the SB Treasury market index), and finally a factor capturing option features (the difference between returns from the SB Medium Term Mortgage index and the SB Medium Term Treasury index).

This bond-pricing model does not generate any significant abnormal returns for a portfolio that uses all the bonds in our sample. However, this bond-pricing model, and others in the literature, ignores shareholder control variables. Therefore, if the expectations inherent in the yields are correct, bonds of firms with high shareholder control and high takeover vulnerability would generate an abnormal return relative to this bond-pricing model by increasing credit risk. The spread and rating results suggests that BLOCK and ATI are complements in being associated with higher yields, particularly for firms that are small and have a low industry-adjusted leverage, reflecting higher takeover vulnerability. As a result, for bonds with both a high BLOCK and high ATI, we would expect positive abnormal bond returns for the current bond-pricing models. In doing so, we also show how abnormal bond returns resulting from a standard bond-pricing model are related to our proxies of shareholder control.

Our sample consists of 75 monthly returns from 1991:1 to 1997:3. The estimated abnormal returns are the constants or alphas in the regressions of excess returns of various bond portfolios on these four factors. 


\section{A. Portfolios sorted on BLOCK and ATI/EXT}

At the beginning of each quarter, we independently sort all firms on BLOCK and on either ATI or EXT. Using BLOCK, we form two groups (with and without an institutional blockholder) while using ATI and EXT, we form three groups - ATI =0, ATI $=1$, ATI $>1$ and EXT $<12,11<$ EXT $<16$, EXT $>15$. The cutoffs for both ATI and EXT were chosen to get the most even distribution of firms over three portfolios. ${ }^{25}$ Thus, we create 2 x $3=6$ portfolios by a two-way sort on ATI (or EXT) and BLOCK. For all portfolios, we compute both the equally-weighted and the value-weighted (using the market value of each bond issue) excess return of all firms' bond issues.

In Table 7, we report the annualized abnormal returns or alphas of several long-short portfolios. First, we estimate the alphas accruing to four portfolios that each buy bonds of firms with a blockholder and sell bonds of firms without a blockholder - one portfolio considers all firms unconditionally and the other three portfolios consider firms conditional on one of the three levels of takeover vulnerability (using ATI or EXT groups). Second, we estimate the alphas accruing to three portfolios that each buy bonds of firms in the highest ATI or EXT category and sell bonds of firms in the lowest ATI or EXT category: again one portfolio considers all firms unconditionally and the other two portfolios consider firms conditional on one of the two groups of shareholder control (using BLOCK). The results are presented in Panel A for ATI and Panel B for EXT.

The long-short portfolio that holds firms with and shorts firms without a blockholder produces a clearly statistically significant annualized abnormal return of $1.25 \%$ for the equally-weighted portfolio (t-stat of 3.44) and of $0.67 \%$ for the value-weighted portfolio (t-stat of 2.74). Interestingly, the long-short portfolios conditional on ATI/EXT show that these abnormal returns are driven by bonds of firms vulnerable to takeovers, providing strong evidence for a complementary relation of BLOCK with ATI/EXT. For the equallyweighted portfolios, the mean returns and the alphas are increasing in the level of both ATI and EXT. For example, the annualized alpha of the long-short portfolio that buys bonds of firms with a blockholder and shorts those without a blockholder equals $0.77 \%$ (t-stat of 1.67) for firms with the lowest level of EXT and equals 1.63\% (t-stat of 2.94) for firms with the highest level of EXT. As a result, the equally-weighted portfolios

\footnotetext{
${ }^{25}$ See Table 1 for the distribution of firms over both ATI and EXT categories.
} 
suggest that blockholding seems only associated with higher abnormal bond returns for firms in the highest ATI or EXT categories.

For ATI, the value-weighted portfolios are fully consistent with the equally-weighted portfolios. However, the value-weighted portfolios using EXT show no pattern in either mean bond returns or alphas. The difference between equal and value-weighted results is suggestive of a size effect, similar to that found for yields and ratings. Before we investigate the role of size in more detail, we consider the importance of ATI and EXT by looking at the returns to a portfolio that buys bonds of firms in the highest ATI or EXT category and shorts those in the lowest category.

The results for using ATI and EXT are presented in Panel C and D, respectively, of Table 7. We find no evidence for any abnormal returns for ATI at all. For EXT, the equally-weighted portfolios show an abnormal return, but only for those firms where there is also a blockholder present, again confirming complementarity. For example, the annualized alpha of such long-short portfolio for firms without a blockholder is $0.27 \%$ (tstat of 0.57 ), and of the portfolio with only firms with a blockholder is $1.13 \%$ (t-stat of 2.32). However, there is no discernible pattern using value-weighted portfolios and EXT, which is, once more, suggestive of a size effect.

\section{B Abnormal returns and the role of firm size and leverage}

We have seen in section 4 that the increase in yield spreads on the appearance of a blockholder is the highest for firms that are small. Consistent with this, we also find in the previous subsection that the abnormal returns are strongest for the equally weighted portfolios. We now directly investigate the role of firm size in generating abnormal returns associated with shareholder control and takeover vulnerability. As the yield results also suggest different bondholder reactions with changing leverage, we investigate if the abnormal returns vary by leverage as well. To investigate how the documented effects of takeover vulnerability and active shareholders on bond abnormal returns are affected by firm-level characteristics such as leverage and firm size, we use the 2-step weighted least squares methodology developed in Cremers and Nair (2003). We briefly describe the procedure below.

The weighted least squares methodology proposed in Cremers and Nair (2003) could be used as an alternative to a panel data approach for the general case of investigating the 
relationship between alphas and firm characteristics and consists of two steps. The first step consists of the estimation of the portfolio alphas using the four-factor bond-pricing model described above, as well as the variance-covariance matrix of these alphas. We form 54 portfolios by sorting all firms independently in four dimensions: ATI (EXT), BLOCK, industry-adjusted leverage (LEV) and the market value of equity (SIZE). We get 54 portfolios by sorting firms into 3 leverage categories and 3 size categories in addition to the pre-existing three categories of ATI (EXT) and two categories of BLOCK $(3 \times 2 \times 3 \times 3=54)$. For each of the 54 groups, we calculate the abnormal returns of the equally-weighted portfolio of all bonds issued by the firms in the group. ${ }^{26}$

In the second step, these alphas are regressed on characteristics using the variancecovariance matrix of the alphas as the weighting matrix. Due to the noise in estimating the alphas of individual bond issues, the sorting of bonds into portfolios along all relevant dimensions greatly increases the methodology's power by reducing idiosyncratic risk. Further, the methodology explicitly accounts for the estimation risk and covariance of the alphas by weighting the alphas by their variance-covariance matrix in the second-step regression. Another important advantage of this method is that it uses the information contained in all 54 alphas, rather than only focusing on the extreme portfolios along a particular dimension. That way, we are still able to detect significant relationships between these alphas, even though the additional sorts on LEV and SIZE reduce the number of bonds in each portfolio. Finally, the quarterly sorts should reduce the noise in each proxy and also override the concern of standard panel methods that typically estimate bond (or firm) alphas that are constant over time.

Before we proceed to investigate the effect of firm size and leverage on how shareholder control is associated with bond returns, we first check - abstracting from issues of corporate governance - if the bond pricing model employed generates any abnormal returns along portfolios based on size and leverage. If the pricing model employed here generates abnormal returns for a sample of firms based on size and leverage, it is then important that these characteristics are first directly controlled before we look at the effect of size and leverage in the interaction of bond returns and governance mechanisms. To this end, in Table 8 we first present the results of regressing alphas on the size and leverage dummies only, without using any governance variables at

\footnotetext{
${ }^{26}$ On average, less than $1.5 \%$ of the portfolios are empty. Further, we also compute value-weighted portfolios, whose results are generally similar to the equally-weighted portfolios, though occasionally with reduced significance. Results are omitted to save space but are available upon request.
} 
all. ${ }^{27}$ These results indeed point toward a systematic role of size and leverage with respect to these alphas. The mispricing of the bonds of small, highly leveraged firms is most severe, with a coefficient of 2.34 (t-stat of 2.3) using ATI and a coefficient of 5.18 (t-stat of 6.9) using EXT. The alphas for these categories of firms, highlighted in table 8, are statistically different from the average alphas. We correct for this mispricing by adding the relevant size-leverage dummies separately to the regressions. ${ }^{28}$

\section{ATI/EXT, BLOCK and SIZE}

We separately investigate the role of SIZE in how ATI, EXT and BLOCK affect the bond portfolio alphas, by running the second-step regression of alphas on the level of either ATI, EXT or BLOCK using three size dummies. ${ }^{29}$ The results using ATI and EXT can be found in Panel B of Table 8. The regressions indicate it is critical to incorporate size. Specifically, we find that fewer anti-takeover provisions, measured by ATI or EXT, as well as the existence of a blockholder are all associated with higher abnormal bond returns. However, this relation is clearly strongest for the group of smallest firms, is generally still apparent for the group of firms of medium size, and is absent for the group of largest firms. For example, the coefficient of ATI equals 0.77 (t-stat of 2.98) for the smallest firms, equals 0.16 (t-stat of 2.1) for the medium size firm, and equals 0.04 (t-stat of 0.56) for the largest firms. Also, the existence of a blockholder generally increases bond alphas especially for the smallest third of firms (by 1.35) in our sample.

Next, we consider the interaction of the existence of active shareholders with the takeover provisions and incorporate both size and leverage. To detect the dependence of these two corporate governance mechanisms, we employ the Min() function, and to detect independence we use the Max() function. Here, min and max denote the minimum and maximum, respectively, among each of the 54 portfolios of their levels of BLOCK and ATI/EXT. These functional forms capture in a simple manner the main difference between the two possibilities. ${ }^{30}$ First, if the two mechanisms were dependent or complements with respect to the bond abnormal returns, an increase in the level of either

\footnotetext{
${ }^{27}$ Here, no intercept can be included in the regressions, in contrast to all regressions using corporate governance variables, where an intercept is included in the regressions but is not reported in the tables.

${ }^{28}$ Various combinations of size and leverage controls produce similar results.

${ }^{29}$ There are two regressions for BLOCK, both for the ATI x BLOCK $x$ SIZE $x$ LEV and the EXT $x$ BLOCK x SIZE x LEV sorted sets of 54 portfolios.

${ }^{30}$ Cremers and Nair (2003) use similar functional forms. The results using ATI/EXT and BLOCK instead of the Min-function are similar and available upon request.
} 
mechanism keeping the other fixed, would not change alphas. In that case, the Maxcoefficient would be insignificant, and the Min-coefficient would be positive and significant. We find that the coefficient on the Max function is insignificant while the coefficient on the Min form is significant - confirming our earlier results that ATI and BLOCK are complements in generating abnormal returns. In what follows we present regressions only using the Min function.

\section{ATI/EXT, BLOCK, SIZE and LEVERAGE}

The results for the interaction of the shareholder control and exposure to takeovers contingent on firm size and leverage is presented in Table 9. We find that BLOCK and ATI/EXT are strong complements in being associated with higher bond alphas mostly for small firms with some evidence that the complementary relation is stronger in small firms with low leverage.

Considering the impact of size in isolation on the interaction between takeover vulnerability and shareholder control, we find no evidence of a complementary relation between these two governance mechanisms for large firms. ${ }^{31}$ Specifically, using ATI the coefficient on the Min-function for small firms equals 1.19 (t-stat of 2.6). If we use EXT, the coefficient on the Min-function is equal to 2.33 (t-stat of 3.5) for small firms. For large firms both these coefficients are insignificant. The minor economic significance for the larger firms is no surprise, given our previous finding that the impact of the corporate governance mechanisms is strongest for the smallest third of firms (as documented in Table 8). Overall, this confirms our findings of the yield spread regressions and the ratings analysis in the previous section. Furthermore, these results can also reconcile the differences between the value- and equally-weighted portfolios in Table 7 as the largest firms dominate the returns of the value-weighted portfolios.

When considering leverage along with size, we find that the coefficient on the Min function (1.33 with a t-stat of 4$)$ is significant only for firms that are small and have low leverage. These results using ATI show that a portfolio that buys bonds of firms with both low takeover protection and high shareholder control and sells bonds of firms without either governance mechanism generates abnormal returns only when the firm is small and has low leverage. While this is consistent with our earlier results and our

${ }^{31}$ Results presented in Table 9 consider both size and leverage. 
hypothesis, the results using EXT are mixed. Specifically, the Min-coefficient for small, low leveraged firms equals 1.38 ( $\mathrm{t}$-stat of 3.9) and for small, high leveraged firms equals 3.20 (t-stat of 2.64). However, the t-statistic of the null hypothesis of both these coefficient being equal is 1.5 , such that this difference is not statistically significant.

In conclusion, the realized bond returns are consistent with the expectations inherent in the yield results and suggest that bondholders require a higher rate of return in the presence of shareholder control when the firm has low takeover defense, is small in size and has low leverage.

\section{Interpretation and Implications}

\section{A. Are the losses related to takeovers?}

We document strong and contrasting bondholder reactions to shareholder control conditional on takeover vulnerability. Bondholder require a higher yield for exposure to shareholder control especially when leverage is low - this is the opposite of what one would expect if risk-shifting were the primary source of conflict. To further mitigate the concern that takeover protection might be proxying for some unrelated source of bondholder loss, we now consider only those bonds that have a poison-put covenant. A poison put covenant gives bondholders the option of selling the issue back to the issuer at par or at a premium upon a change of control in the issuer. Poison puts are often used when a company fears an unwanted takeover by protecting bondholders for the eventuality of a successful hostile takeover triggering an event that substantially reduces the value of the bonds (see Datta (1996) and Asquith and Wizman (1990)).

Table 10 documents the results of the fixed effects yield spread regressions for this sample when ATI is used as an index of takeover vulnerability. Results using EXT are similar and are not reported. The number of firms for which we have information on the covenants is 561 with an average of 4.18 issues per firm. The number of firms with the poison put covenant is 137 with an average of 1.73 issues per firm. The results show that the coefficients on BLOCK and on the interaction between ATI and BLOCK are not significant for the sample with the poison put covenant. Since we have 2,393 observations in total, this result is unlikely due to a small sample. Further, the direction of impact also appears to be considerably lower and in some cases, the opposite of what we 
have in the full sample (see model 7 in table 9). We also find that the conflict is now higher for firms with higher leverage - we find that the appearance of a blockholder increases yield spreads of small firms with low takeover protection only if they have high leverage. This is more supportive of risk shifting as the source of bondholder loss. Therefore, the result shown in the previous sections are stronger for those bonds that are not protected by the poison put covenant. This further strengthens our evidence that it is indeed the losses during hostile takeovers that the bondholders price.

\section{B. Hostile Takeovers and Leverage}

What is it about hostile takeovers that bondholders fear? As discussed earlier, one possible channel of bondholder loss is an increase in leverage. In the 80 's, due to the predominance of LBOs, this is was an obvious concern (see e.g., Warga and Welch, 1993). However, this is less obvious in the 1990's and so we document how leverage changes for hostile targets in the more recent period.

Using SDC and excluding open market purchases, we detect 80 hostile takeovers in our sample. To classify the bid as hostile, we use the same algorithm used by Lehn and Mitchell (1989). Out of these, we consider the 26 completed hostile takeovers only, as we are interested in leverage changes after the takeover. Further, we are able to detect the acquirer and get quarterly leverage data for only 16 of these completed deals. Although our sample is small, we find that for each one of these 16 cases, the leverage increases after the takeover. The graph for average leverage around the takeover announcement quarter is shown in Figure 2. The average increase is significant and the expectation of higher leverage post takeovers could drive ex-ante bondholders expectations.

\section{Conclusion}

We investigate the effect of shareholder control on bondholder wealth and document that shareholder control can have contrasting effects on bond yields, ratings and returns, depending on the takeover vulnerability of a firm. Using the presence of an institutional blockholder to proxy for shareholder control and firm-level anti-takeover provisions to proxy for takeover vulnerability, we find that shareholder control is associated with lower yields if the firm is protected from takeovers. We also find that shareholder control 
is associated with higher yields if the firm is exposed to takeovers. The contrasting effects of shareholder control on yields are the strongest for firms that are small and have low leverage. In the presence of shareholder control, the difference in bond yields due to differences in takeover vulnerability can be as high as 93 basis points.

That the bondholder reactions are related to hostile takeovers is further confirmed by the fact that the results are insignificant for a subsample of firms where the bondholders are protected from takeovers through the poison put covenant. While losses in these hostile takeovers could be due to an increase in leverage, other sources of losses could exist and is left for future investigation. Another avenue of future research is to investigate the role of firm-specific control factors in bond-pricing models, especially since portfolios that long firms with both strong shareholder control and high takeover vulnerability and short firms without either shareholder control or takeover vulnerability generate an annualized abnormal return of $1 \%$ to $1.6 \%$ for portfolios. Finally, by showing that a complementary design of two governance mechanisms - shareholder control and takeover exposure - increases the cost of debt, the paper suggests that the design of different governance mechanisms should be related to the capital structure of the firm. 


\section{References}

Andrade, Gregor, Mark L. Mitchell, and Erik Stafford (2001), "New evidence and perspectives on mergers", Journal of Economic Perspectives 15, 103-120.

Asquith, P., T.A. Wizman (1990), "Event risk, covenants, and bondholder returns in leveraged buyouts", Journal of Financial Economics, 27(1), 195 - 213

Bagnani, E.S., N. T. Milonas, A. Saunders, and N. G. Travlos (1994), "Managers, owners, and the pricing of risky debt: An empirical analysis", Journal of Finance, 49, 453-477

Bhojraj, S. and P. Sengupta (2003), "The effect of corporate governance mechanisms on bond ratings and yields: The role of institutional investors and outside directors", Journal of Business, 76, 455-475

Billet, M.T., T.D. King, and D.C. Mauer (2004), "Bondholder Wealth Effects in Mergers and Acquisitions: New Evidence from the 1980s and 1990s," Journal of Finance, 59, 107135

Billett, M. T. (1996), "Targeting capital structure: The relationship between risky debt and the firm's likelihood of being acquired", Journal of Business 69, 173-192.

Black, B. S. (1998), Shareholder activism and corporate governance in the United States, in P. Newman, ed., The New Palgrave Dictionary of Economics and the Law, Palgrave, London, UK

Blume, M.E., F. Lim and A.C. MacKinlay (1998), "The declining credit quality of US corporate debt: Myth or reality?” Journal of Finance, 53, 1389-1413

Campbell, J.Y., and G.B. Taksler (2003), "Equity Volatility and Corporate Bond Yields," Journal of Finance, 58, 2321-2350

Coates IV, J., G. Subramanian and L. A. Bebchuk (2002), The Powerful Antitakeover Force of Staggered Boards: Theory, Evidence Policy, Stanford Law Review, 54, 887-951.

Cook, D. O., and J. C. Easterwood (1994), "Poison put bonds: An analysis of their economic role", Journal of Finance 49, 1905-1920.

Daines, R. and M. Klausner (2001), "Do IPO Charters Maximize Firm Value? Anti-takeover Provisions in IPOs," Journal of Law, Economics, and Organization, Vol. 17, 83-120.

Datta, S., M.I. Datta (1996), "Takeover defenses and wealth effects on security holders: The case of poison pill adoptions", Journal of Banking and Finance, 20(7), 1231-1250

Eberhart, A. C., and A. Siddique (2002), "The long-term performance of corporate bonds (and stocks) following seasoned equity offerings", Review of Financial Studies 15, 1385-1406.

Elton, E.J., M.J. Gruber, D. Agrawal, and C. Mann (2001), "Explaining the rate spread on corporate bonds," Journal of Finance, 56, 247-277. 
Elton, E.J., M.J. Gruber, and C.R. Blake (1995), "Fundamental economic variables, expected returns and bond return performance," Journal of Finance, 50, 1229-1256

Fama, E. F., and K. R. French (1997), "Industry Costs of Equity," Journal of Financial Economics, 93, 153- 194

Fama, E. F., and J. D. MacBeth (1973), "Risk, Return, and Equilibrium: Empirical Tests," Journal of Political Economy, 81, 607-636

Fama, E.F., and K.R. French (2001), "Disappearing dividends: Changing firm characteristics or lower propensity to pay?” Journal of Financial Economics, 60, 3-44

Flannery, M., and S. Sorescu (1996), "Evidence of Bank Market Discipline in Subordinated Debenture Yields: 1983-1991," Journal of Finance, 51, 1347-1377

Galai, D. and R. Masulis (1976), "The option pricing model and the risk factor of stock", Journal of Financial Economics 3, 53-81

Gompers, P.A., J.L. Ishi, and A. Metrick (2003), "Corporate governance and equity prices," The Quarterly Journal of Economics, Vol. 118

Gompers, P.A. and A. Metrick (2001), "Institutional Investors and Equity Prices”, The Quarterly Journal of Economics, 116(1), 229-259.

Greene, W. H. (2003), Econometric Analysis, Prentice Hall, Englewood Cliffs, NJ

Handjinicolaou, G., and A. Kalay (1984), "Wealth redistributions or changes in firm value: An analysis of returns to bondholders and stockholders around dividend announcements", Journal of Financial Economics, 13, 35-63

Harris, M. and A. Raviv (1988), "Corporate Control Contests and Capital Structure," Journal of Financial Economics, 55-86.

Holmstrom, B., and S. N. Kaplan (2001), "Corporate governance and merger activity in the United States: Making sense of the 1980s and 1990s", Journal of Economic Perspectives $15,121-144$

Hong, G., and A. Warga (2000), "An empirical study of bond market transactions", Financial Analysts Journal 56, 32-46

Kim, E. H., and J. J. McConnell (1977), "Corporate mergers and the co-insurance of corporate debt", Journal of Finance 32, 349-365

Lehn, K., and A. Poulsen (1991), "Contractual resolution of bondholder-stockholder conflicts in leveraged buyouts", Journal of Law and Economics, 34, 645-673

Maxwell, W. F., and C P. Stephens (2003), "The wealth effects of repurchases on bondholders", Journal of Finance, 895-919 
Maxwell, W. F., and R. Rao (2003), "Do Spin-offs Expropriate Wealth from Bondholders?" Journal of Finance, 2087-2108

Sarbanes, Paul and Michael G. Oxley (2002), "Sarbanes-Oxley Act", Report by the House Financial Services committee.

Schwert, G. William (2000), "Hostility in takeovers: In the eyes of the beholder?" Journal of Finance 55, 2599-2640

Shleifer, A and R.Vishny (1986), "Large Shareholders and Corporate Control," Journal of Political Economy

Shleifer, A and R.Vishny (1997), "A Survey of Corporate Governance," Journal of Finance, 52, 737-783

Stulz, R.M. (1988), "Managerial Control of Voting Rights: Financing Policies and the Market for Corporate Control," Journal of Financial Economics, 25-54.

Sweeney, R. J., A. Warga, and D. Winters (1997), "The Market Value of Debt, Market Versus Book Value of Debt, and Returns to Assets," Financial Management; 26, 5-21

Warga, A., and I. Welch (1993), "Bondholder losses in leveraged buyouts", Review of Financial Studies 6, 959-982

Zwiebel, J. (1996), "Dynamic Capital Structure under Managerial Entrenchment," American Economic Review, 86, 1197-1215. 
Figure 1. Timeline

Bonds issued $\quad$ Bidder appears with probability $t$

Cash flows realized

\begin{tabular}{l|ll|} 
& & \\
\hline & & $\mathbf{T}=\mathbf{2}$
\end{tabular}




\section{Figure 2. Leverage changes for completed hostile takeovers}

The graph below shows the average leverage of firms that were hostile targets. Time 0 signifies the quarter during which the takeover-announcement was made. We use a sample of 16 completed hostile takeovers in our time period of 1990 - 1997 for which we were able to get all relevant leverage data.

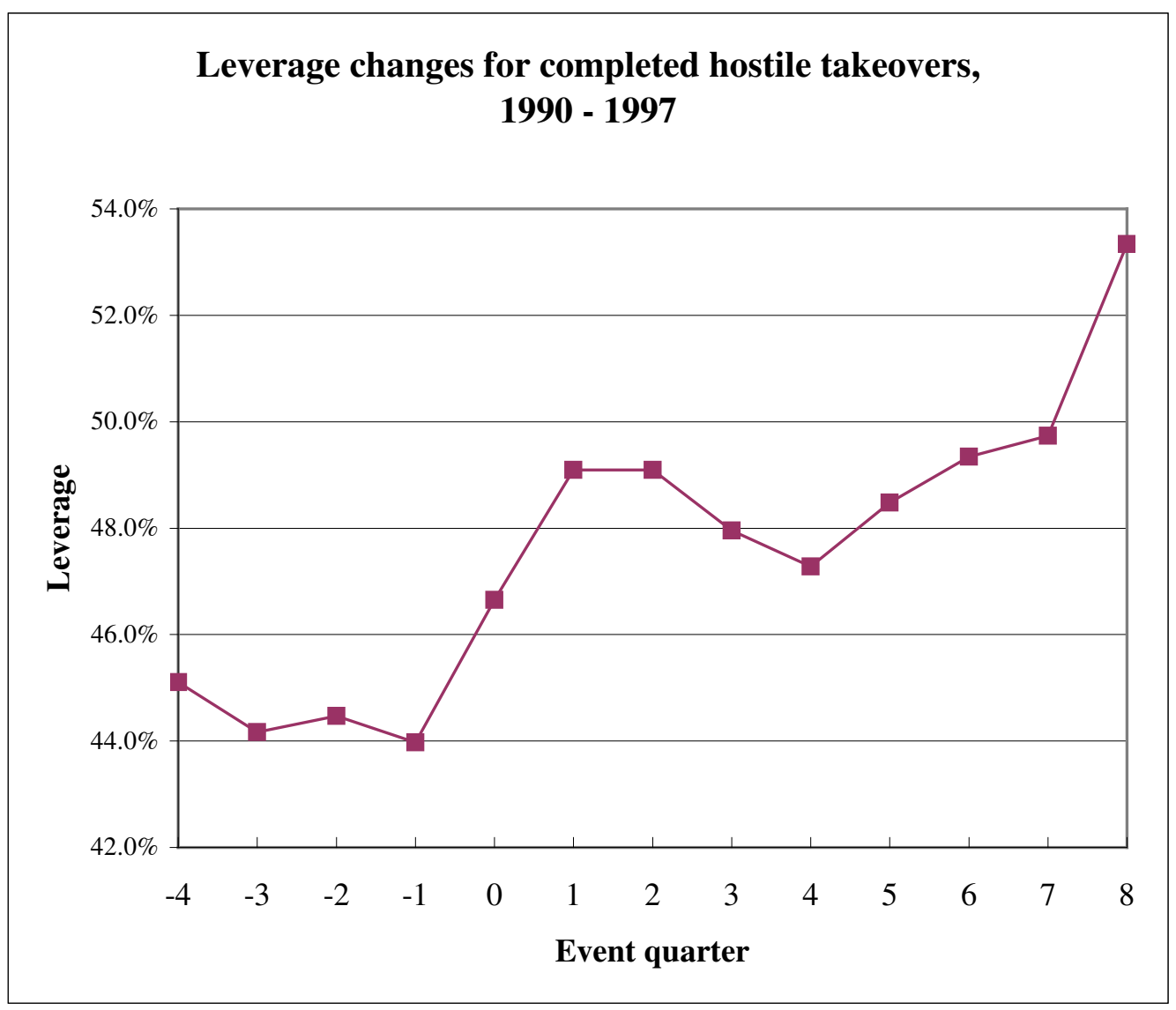




\section{Table 1. Number of firms and issues, percentiles of BLOCK, EXT and ATI}

The table presents the following summary statistics for the first quarters of the years 1991 to 1997 as found in our sample: the average number of firms and bond issues; the $25 \%, 50 \%$ and $75 \%$ percentiles of the percentage of shares held by the largest institutional blockholder (minimum 5\%, BLOCK); the 25\%, 50\% and $75 \%$ percentiles of the shareholder rights index EXT (see Gompers, Ishi and Metrick (2003)); and finally the percentages of firms in the four anti-takeover index (ATI) groups.

\begin{tabular}{|c|c|c|c|c|c|c|c|}
\hline Year & 1991 & 1992 & 1993 & 1994 & 1995 & 1996 & 1997 \\
\hline Number of Firms & 365 & 431 & 473 & 402 & 452 & 449 & 411 \\
\hline Number of Issues & 1596 & 2003 & 2141 & 1717 & 1895 & 1863 & 1655 \\
\hline Issues/firm & 4.37 & 4.65 & 4.53 & 4.27 & 4.19 & 4.15 & 4.03 \\
\hline $25 \%$ percentile of largest block & $0.00 \%$ & $0.00 \%$ & $0.00 \%$ & $0.00 \%$ & $0.00 \%$ & $0.00 \%$ & $0.00 \%$ \\
\hline $50 \%$ percentile of largest block & $5.35 \%$ & $5.20 \%$ & $5.47 \%$ & $5.22 \%$ & $5.42 \%$ & $5.81 \%$ & $6.11 \%$ \\
\hline $75 \%$ percentile of largest block & $8.78 \%$ & $7.74 \%$ & $7.99 \%$ & $7.84 \%$ & $8.73 \%$ & $9.02 \%$ & $9.25 \%$ \\
\hline $25 \%$ percentile of $\%$ EXT & 12 & 13 & 12 & 12 & 13 & 12 & 12 \\
\hline $50 \%$ percentile of $\%$ EXT & 14 & 15 & 15 & 14 & 14 & 15 & 14 \\
\hline $75 \%$ percentile of $\%$ EXT & 16 & 17 & 17 & 16 & 17 & 16 & 16 \\
\hline$\%$ of firms with ATI $=0$ & $32.0 \%$ & $29.2 \%$ & $30.6 \%$ & $31.9 \%$ & $31.6 \%$ & $34.0 \%$ & $33.6 \%$ \\
\hline$\%$ of firms with ATI = 1 & $26.4 \%$ & $27.5 \%$ & $28.5 \%$ & $34.0 \%$ & $33.5 \%$ & $35.8 \%$ & $37.0 \%$ \\
\hline$\%$ of firms with ATI $=2$ & $37.1 \%$ & $38.6 \%$ & $35.8 \%$ & $30.5 \%$ & $30.8 \%$ & $24.9 \%$ & $24.4 \%$ \\
\hline$\%$ of firms with ATI = 3 & $4.6 \%$ & $4.6 \%$ & $5.1 \%$ & $3.6 \%$ & $4.1 \%$ & $5.3 \%$ & $5.0 \%$ \\
\hline
\end{tabular}




\section{Table 2. Correlation matrix of EXT, ATI, BLOCK, LEV}

The table presents the correlations of the following six variables, all pooled across time and firms: the shareholder rights indices ATI and EXT; the existence of an institutional blockholder BLOCK-holder; the market capitalization (SIZE); and the industry-adjusted leverage (LEV); and the firm's RATING. The higher the value for RATING, the lower the expected bankruptcy probability. Specifically, we use S\&P ratings categories on a scale from 22 to 2 , with e.g. $\mathrm{AAA}=22, \mathrm{BB}+=12$ and $\mathrm{C}=2$.

\begin{tabular}{l|rrrrr}
\multicolumn{1}{l|}{ EXT } & ATI & BLOCK & SIZE & LEVERAGE \\
\hline ATI & $65.77 \%$ & & & & \\
BLOCK & $-6.73 \%$ & $-3.99 \%$ & & & \\
SIZE & $-0.13 \%$ & $-1.34 \%$ & $-24.50 \%$ & & \\
LEVERAGE & $-3.26 \%$ & $-3.60 \%$ & $15.22 \%$ & $-1.04 \%$ & \\
RATING & $1.15 \%$ & $0.18 \%$ & $-29.69 \%$ & $56.64 \%$ & $-26.18 \%$
\end{tabular}




\section{Table 3, panel A. Effect of shareholder control on bond spreads: ATI}

Reported are the pooled OLS regression coefficients plus their t-statistics in parentheses of regressing monthly corporate bond spreads on the governance variables ATI and BLOCK (see Table 1 for a description), a constant (omitted), plus a set of controls, where TTM denotes the bond's time to maturity in years, $\mathrm{C}$ is a dummy for callability, and CR2 to CR7 are dummies for rating categories AA+ to B-. Dummies indicating the $33 \%$ of largest/smallest firms are $\mathrm{I}_{\text {large }}$ and $\mathrm{I}_{\text {small }}$, those indicating the $33 \%$ of firms with highest and lowest leverage are $\mathrm{I}_{\text {highlev }}$ and $\mathrm{I}_{\text {lowlev }}$. Our sample includes an average of 1,839 bonds per year from 1990 to 1997 , with on average 4.3 corporate bond issues per firm.

\begin{tabular}{|c|c|c|c|c|c|c|c|}
\hline MODEL & 1 & 2 & 3 & 4 & 5 & 6 & 7 \\
\hline$\overline{\text { BLOCK }}$ & $\begin{array}{c}0.01 \\
(0.73)\end{array}$ & & & $\begin{array}{c}-0.24 \\
(-7.24)\end{array}$ & $\begin{array}{c}-0.23 \\
(-6.89)\end{array}$ & $\begin{array}{c}-0.24 \\
(-7.20)\end{array}$ & $\begin{array}{c}-0.24 \\
(-6.98)\end{array}$ \\
\hline ATI & & $\begin{array}{c}\mathbf{0 . 0 6} \\
(7.67)\end{array}$ & & $\begin{array}{c}-0.01 \\
(-0.78)\end{array}$ & $\begin{array}{c}-0.01 \\
(-1.08)\end{array}$ & $\begin{array}{c}-0.01 \\
(-0.76)\end{array}$ & $\begin{array}{l}-0.01 \\
(-0.94)\end{array}$ \\
\hline ATI*BLOCK & & & $\begin{array}{c}0.04 \\
(6.81)\end{array}$ & $\begin{array}{c}0.12 \\
(8.30)\end{array}$ & $\begin{array}{c}\mathbf{0 . 1 1} \\
(7.02)\end{array}$ & $\begin{array}{c}0.12 \\
(7.41)\end{array}$ & $\begin{array}{c}\mathbf{0 . 1 2} \\
(7.78)\end{array}$ \\
\hline ATI*BLOCK*I $\mathbf{I}_{\text {large }}$ & & & & & $\begin{array}{c}-0.01 \\
(-0.51)\end{array}$ & & \\
\hline ATI*BLOCK* $\mathbf{I}_{\text {small }}$ & & & & & $\begin{array}{c}0.12 \\
(9.74)\end{array}$ & & \\
\hline ATI*BLOCK*I $\mathbf{I}_{\text {highlev }}$ & & & & & & $\begin{array}{c}0.01 \\
(1.11)\end{array}$ & \\
\hline ATI*BLOCK*I I Iowlev & & & & & & $\begin{array}{l}0.001 \\
(0.06)\end{array}$ & \\
\hline ATI*BLOCK $* \mathbf{I}_{\text {large, highlev }}$ & & & & & & & $\begin{array}{c}-0.02 \\
(-1.65)\end{array}$ \\
\hline ATI*BLOCK* $\mathbf{I}_{\text {large, lowlev }}$ & & & & & & & $\begin{array}{c}-0.02 \\
(-1.42)\end{array}$ \\
\hline ATI*BLOCK* $\mathbf{I}_{\text {small, highlev }}$ & & & & & & & $\begin{array}{c}0.07 \\
(4.79)\end{array}$ \\
\hline ATI*BLOCK*I $\mathbf{I}_{\text {small, lowlev }}$ & & & & & & & $\begin{array}{c}0.10 \\
(4.80)\end{array}$ \\
\hline LEVERAGE & $\begin{array}{c}0.32 \\
(7.67)\end{array}$ & $\begin{array}{c}0.32 \\
(7.64)\end{array}$ & $\begin{array}{c}0.31 \\
(7.40)\end{array}$ & $\begin{array}{c}0.34 \\
(8.07)\end{array}$ & $\begin{array}{c}0.37 \\
(8.77)\end{array}$ & $\begin{array}{c}0.31 \\
(6.47)\end{array}$ & $\begin{array}{c}0.36 \\
(7.89)\end{array}$ \\
\hline LN ASSETS & $\begin{array}{c}-0.08 \\
(-6.24)\end{array}$ & $\begin{array}{c}-0.08 \\
(-6.87)\end{array}$ & $\begin{array}{c}-0.07 \\
(-5.94)\end{array}$ & $\begin{array}{c}-0.08 \\
(-6.80)\end{array}$ & $\begin{array}{c}-0.06 \\
(-4.84)\end{array}$ & $\begin{array}{c}-0.08 \\
(-6.73)\end{array}$ & $\begin{array}{c}-0.07 \\
(-5.71)\end{array}$ \\
\hline TTM & $\begin{array}{l}-0.001 \\
(-1.30)\end{array}$ & $\begin{array}{l}-0.001 \\
(-0.88)\end{array}$ & $\begin{array}{l}-0.001 \\
(-1.32)\end{array}$ & $\begin{array}{l}-0.001 \\
(-1.37)\end{array}$ & $\begin{array}{l}-0.001 \\
(-1.18)\end{array}$ & $\begin{array}{l}-0.001 \\
(-1.38)\end{array}$ & $\begin{array}{l}-0.001 \\
(-1.27)\end{array}$ \\
\hline SENIOR & $\begin{array}{l}-0.021 \\
(-0.97)\end{array}$ & $\begin{array}{l}-0.013 \\
(-0.58)\end{array}$ & $\begin{array}{l}-0.018 \\
(-0.83)\end{array}$ & $\begin{array}{l}-0.006 \\
(-0.26)\end{array}$ & $\begin{array}{l}-0.001 \\
(-0.03)\end{array}$ & $\begin{array}{l}-0.007 \\
(-0.32)\end{array}$ & $\begin{array}{l}-0.002 \\
(-0.11)\end{array}$ \\
\hline SENIOR SECURED & $\begin{array}{c}-0.28 \\
(-11.16)\end{array}$ & $\begin{array}{c}-0.31 \\
(-12.18)\end{array}$ & $\begin{array}{c}-0.28 \\
(-10.93)\end{array}$ & $\begin{array}{c}-0.30 \\
(-11.87)\end{array}$ & $\begin{array}{c}-0.29 \\
(-11.15)\end{array}$ & $\begin{array}{c}-0.30 \\
(-11.65)\end{array}$ & $\begin{array}{c}-0.29 \\
(-11.45)\end{array}$ \\
\hline C & $\begin{array}{c}0.69 \\
(43.87)\end{array}$ & $\begin{array}{c}0.69 \\
(43.92)\end{array}$ & $\begin{array}{c}0.70 \\
(44.08)\end{array}$ & $\begin{array}{c}0.69 \\
(43.94)\end{array}$ & $\begin{array}{c}0.70 \\
(44.01)\end{array}$ & $\begin{array}{c}0.69 \\
(43.93)\end{array}$ & $\begin{array}{c}0.69 \\
(43.86)\end{array}$ \\
\hline CR2 & $\begin{array}{c}0.15 \\
(1.98)\end{array}$ & $\begin{array}{l}0.15 \\
(2.03)\end{array}$ & $\begin{array}{c}0.16 \\
(2.08)\end{array}$ & $\begin{array}{c}0.17 \\
(2.21)\end{array}$ & $\begin{array}{c}0.16 \\
(2.19)\end{array}$ & $\begin{array}{c}0.17 \\
(2.23)\end{array}$ & $\begin{array}{c}0.17 \\
(2.23)\end{array}$ \\
\hline CR3 & $\begin{array}{c}0.37 \\
(5.02)\end{array}$ & $\begin{array}{c}0.39 \\
(5.36)\end{array}$ & $\begin{array}{c}0.37 \\
(5.07)\end{array}$ & $\begin{array}{c}0.40 \\
(5.47)\end{array}$ & $\begin{array}{c}0.39 \\
(5.37)\end{array}$ & $\begin{array}{l}0.40 \\
(5.50)\end{array}$ & $\begin{array}{c}0.40 \\
(5.42)\end{array}$ \\
\hline CR4 & $\begin{array}{c}0.77 \\
(10.41)\end{array}$ & $\begin{array}{c}0.80 \\
(10.78)\end{array}$ & $\begin{array}{c}0.76 \\
(10.29)\end{array}$ & $\begin{array}{c}0.79 \\
(10.72)\end{array}$ & $\begin{array}{c}0.75 \\
(10.19)\end{array}$ & $\begin{array}{c}0.80 \\
(10.76)\end{array}$ & $\begin{array}{c}0.77 \\
(10.44)\end{array}$ \\
\hline CR5 & $\begin{array}{l}2.1769 \\
(27.89)\end{array}$ & $\begin{array}{c}2.21 \\
(28.31)\end{array}$ & $\begin{array}{c}2.16 \\
(27.79)\end{array}$ & $\begin{array}{c}2.21 \\
(28.36)\end{array}$ & $\begin{array}{c}2.11 \\
(26.92)\end{array}$ & $\begin{array}{c}2.22 \\
(28.38)\end{array}$ & $\begin{array}{c}2.16 \\
(27.59)\end{array}$ \\
\hline CR6 & $\begin{array}{c}4.38 \\
(52.57)\end{array}$ & $\begin{array}{c}4.40 \\
(52.96)\end{array}$ & $\begin{array}{c}4.36 \\
(52.42)\end{array}$ & $\begin{array}{c}4.40 \\
(52.84)\end{array}$ & $\begin{array}{c}4.22 \\
(49.82)\end{array}$ & $\begin{array}{c}4.40 \\
(52.81)\end{array}$ & $\begin{array}{c}4.30 \\
(50.69)\end{array}$ \\
\hline $\begin{array}{l}\text { CR7 } \\
\text { adjusted R2 }\end{array}$ & $\begin{array}{c}10.88 \\
(59.00) \\
37.54 \%\end{array}$ & $\begin{array}{c}10.89 \\
(59.11) \\
37.63 \%\end{array}$ & $\begin{array}{c}10.85 \\
(58.89) \\
37.61 \%\end{array}$ & $\begin{array}{c}10.87 \\
(59.05) \\
37.74 \%\end{array}$ & $\begin{array}{c}10.65 \\
(57.56) \\
37.92 \%\end{array}$ & $\begin{array}{c}10.87 \\
(59.04) \\
37.74 \%\end{array}$ & $\begin{array}{c}10.73 \\
(58.02) \\
37.81 \%\end{array}$ \\
\hline
\end{tabular}


Table 3, panel B. Effect of shareholder control on bond spreads: ATI + fixed issuer effects

Reported are the pooled OLS regression coefficients plus their t-statistics in parentheses of regressing monthly corporate bond spreads on the governance variables ATI and BLOCK (see Table 1 for a description), a constant, a set of controls (see panel A), plus issuer dummies. Only the results for the governance variables are reported. Dummies indicating the $33 \%$ of largest/smallest firms are $\mathrm{I}_{\text {large }}$ and $\mathrm{I}_{\text {small }}$, those indicating the $33 \%$ of firms with highest and lowest leverage are $\mathrm{I}_{\text {highlev }}$ and $\mathrm{I}_{\text {lowlev }}$. Our sample includes an average of 1,839 bonds per year from 1990 to 1997, with on average 4.3 corporate bond issues per firm.

\begin{tabular}{|c|c|c|c|c|c|c|c|}
\hline MODEL & 1 & 2 & 3 & 4 & 5 & 6 & 7 \\
\hline$\overline{\text { BLOCK }}$ & $\begin{array}{c}0.07 \\
(4.16)\end{array}$ & & & $\begin{array}{c}-0.15 \\
(-3.61)\end{array}$ & $\begin{array}{c}-0.14 \\
(-3.39)\end{array}$ & $\begin{array}{c}-0.15 \\
(-3.59)\end{array}$ & $\begin{array}{c}-0.15 \\
(-3.47)\end{array}$ \\
\hline ATI & & $\begin{array}{c}0.06 \\
(2.79)\end{array}$ & & $\begin{array}{c}0.02 \\
(0.86)\end{array}$ & $\begin{array}{c}0.01 \\
(0.57)\end{array}$ & $\begin{array}{c}0.02 \\
(0.83)\end{array}$ & $\begin{array}{c}0.02 \\
(1.00)\end{array}$ \\
\hline ATI*BLOCK & & & $\begin{array}{c}0.04 \\
(6.38)\end{array}$ & $\begin{array}{c}0.10 \\
(5.69)\end{array}$ & $\begin{array}{c}0.13 \\
(6.63)\end{array}$ & $\begin{array}{c}0.12 \\
(6.03)\end{array}$ & $\begin{array}{c}0.12 \\
(6.18)\end{array}$ \\
\hline ATI*BLOCK*I Iarge & & & & & $\begin{array}{c}-0.09 \\
(-7.67)\end{array}$ & & \\
\hline ATI*BLOCK*I $\mathbf{I}_{\text {small }}$ & & & & & $\begin{array}{c}0.18 \\
(12.61)\end{array}$ & & \\
\hline ATI*BLOCK* $\mathbf{I}_{\text {highlev }}$ & & & & & & $\begin{array}{c}-0.04 \\
(-3.58)\end{array}$ & \\
\hline ATI*BLOCK* $\mathbf{I}_{\text {lowlev }}$ & & & & & & $\begin{array}{c}0.01 \\
(\mathbf{0 . 7 8})\end{array}$ & \\
\hline ATI*BLOCK $* \mathbf{I}_{\text {large, highlev }}$ & & & & & & & $\begin{array}{c}-0.07 \\
(-5.57)\end{array}$ \\
\hline ATI*BLOCK* $\mathbf{I}_{\text {large, lowlev }}$ & & & & & & & $\begin{array}{c}-0.05 \\
(-3.12)\end{array}$ \\
\hline ATI*BLOCK*I Ismall, highlev & & & & & & & $\begin{array}{c}0.05 \\
(2.96)\end{array}$ \\
\hline ATI*BLOCK*I $\mathbf{I}_{\text {small, lowlev }}$ & & & & & & & $\begin{array}{c}0.19 \\
(7.82)\end{array}$ \\
\hline
\end{tabular}




\section{Table 4. Effect of shareholder control on bond spreads: EXT}

Reported are the pooled OLS regression coefficients plus their t-statistics in parentheses of regressing monthly corporate bond spreads on the governance variables EXT and BLOCK (see Table 1 for a description), a constant, a set of controls (see Table 3, panel A). Only the results for the governance variables are reported. Dummies indicating the $33 \%$ of largest/smallest firms are $\mathrm{I}_{\text {large }}$ and $\mathrm{I}_{\text {small }}$, those indicating the $33 \%$ of firms with highest and lowest leverage are $\mathrm{I}_{\text {highlev }}$ and $\mathrm{I}_{\text {lowlev }}$. Our sample includes an average of 1,839 bonds per year from 1990 to 1997, with on average 4.3 corporate bond issues per firm.

\begin{tabular}{|c|c|c|c|c|c|c|c|}
\hline MODEL & 1 & 2 & 3 & 4 & 5 & 6 & 7 \\
\hline$\overline{\text { BLOCK }}$ & $\begin{array}{c}0.01 \\
(0.73)\end{array}$ & & & $\begin{array}{c}-0.32 \\
(-4.49)\end{array}$ & $\begin{array}{c}-0.37 \\
(-5.17)\end{array}$ & $\begin{array}{c}-0.32 \\
(-4.49)\end{array}$ & $\begin{array}{c}-0.33 \\
(-4.62)\end{array}$ \\
\hline EXT & & $\begin{array}{l}0.009 \\
(3.44)\end{array}$ & & $\begin{array}{l}-0.004 \\
(-1.03)\end{array}$ & $\begin{array}{l}-0.005 \\
(-1.37)\end{array}$ & $\begin{array}{l}-0.004 \\
(-1.02)\end{array}$ & $\begin{array}{l}-0.004 \\
(-1.18)\end{array}$ \\
\hline EXT*BLOCK & & & $\begin{array}{l}\mathbf{0 . 0 0 2} \\
(2.27)\end{array}$ & $\begin{array}{l}0.023 \\
(4.71)\end{array}$ & $\begin{array}{l}\mathbf{0 . 0 2 7} \\
(\mathbf{5 . 3 9})\end{array}$ & $\begin{array}{l}0.022 \\
(4.53)\end{array}$ & $\begin{array}{c}0.024 \\
(4.87)\end{array}$ \\
\hline EXT*BLOCK*I I Iarge & & & & & $\begin{array}{l}-0.004 \\
(-2.99)\end{array}$ & & \\
\hline $\mathbf{E X T}^{*} \mathrm{BLOCK}^{*} \mathbf{I}_{\text {small }}$ & & & & & $\begin{array}{c}0.01 \\
(6.61)\end{array}$ & & \\
\hline EXT*BLOCK*I $\mathbf{I}_{\text {highlev }}$ & & & & & & $\begin{array}{c}0.0001 \\
(0.03)\end{array}$ & \\
\hline EXT*BLOCK* $\mathbf{I}_{\text {lowlev }}$ & & & & & & $\begin{array}{l}0.002 \\
(1.00)\end{array}$ & \\
\hline EXT*BLOCK* $\mathbf{I}_{\text {large, highlev }}$ & & & & & & & $\begin{array}{r}-0.006 \\
(-3.32)\end{array}$ \\
\hline EXT*BLOCK $* \mathbf{I}_{\text {large, lowlev }}$ & & & & & & & $\begin{array}{l}-0.001 \\
(-0.40)\end{array}$ \\
\hline EXT*BLOCK* $\mathbf{I}_{\text {small, highlev }}$ & & & & & & & $\begin{array}{l}0.009 \\
(3.76)\end{array}$ \\
\hline EXT*BLOCK* $\mathbf{I}_{\text {small, lowlev }}$ & & & & & & & $\begin{array}{c}0.011 \\
(3.39)\end{array}$ \\
\hline
\end{tabular}




\section{Table 5. Effect of shareholder control on ratings: ATI}

Reported are the results from an ordered probit model to relate corporate bond ratings to the governance variables ATI and BLOCK (see Table 1 for a description), a constant (omitted), plus a set of controls, where TTM denotes the bond's time to maturity in years and C is a dummy for callability. Dummies indicating the $33 \%$ of largest/smallest firms are $I_{\text {large }}$ and $I_{\text {small }}$, those indicating the $33 \%$ of firms with highest and lowest leverage are $\mathrm{I}_{\text {highlev }}$ and $\mathrm{I}_{\text {lowlev }}$. We first estimate the probit regressions across bonds per quarter and the report the time series average of the coefficients and their t-statistics between parentheses. We use a 7-way classification representing $\mathrm{S} \& \mathrm{P}$ ratings (closest to) AAA, AA, BBB, BB, B, CCC, and lower. Our sample includes an average of 1,839 bonds per year from 1990 to 1997 , with on average 4.3 corporate bond issues per firm.

\begin{tabular}{|c|c|c|c|c|c|c|c|}
\hline MODEL & 1 & 2 & 3 & 4 & 5 & 6 & 7 \\
\hline BLOCK & \begin{tabular}{|c|}
-0.48 \\
$(-18.44)$
\end{tabular} & & & $\begin{array}{c}-0.11 \\
(-2.03)\end{array}$ & $\begin{array}{c}-0.19 \\
(-3.38)\end{array}$ & $\begin{array}{c}-0.10 \\
(-1.92)\end{array}$ & $\begin{array}{c}-0.21 \\
(-3.52)\end{array}$ \\
\hline ATI & & $\begin{array}{c}0.10 \\
(10.13)\end{array}$ & & $\begin{array}{c}0.20 \\
(11.02)\end{array}$ & $\begin{array}{c}0.22 \\
(10.64)\end{array}$ & $\begin{array}{c}0.20 \\
(10.99)\end{array}$ & $\begin{array}{c}0.22 \\
(\mathbf{1 0 . 9 5})\end{array}$ \\
\hline ATI*BLOCK & & & $\begin{array}{c}-0.15 \\
(-12.86)\end{array}$ & $\begin{array}{c}-0.18 \\
(-6.93)\end{array}$ & $\begin{array}{c}-0.23 \\
(-7.92)\end{array}$ & $\begin{array}{c}-0.31 \\
(-9.91)\end{array}$ & $\begin{array}{c}-0.22 \\
(-7.28)\end{array}$ \\
\hline ATI*BLOCK* $\mathbf{I}_{\text {large }}$ & & & & & $\begin{array}{c}0.33 \\
(20.70)\end{array}$ & & \\
\hline ATI*BLOCK* $\mathbf{I}_{\text {small }}$ & & & & & $\begin{array}{c}-0.43 \\
(-27.91)\end{array}$ & & \\
\hline ATI*BLOCK $* \mathbf{I}_{\text {highlev }}$ & & & & & & $\begin{array}{c}0.17 \\
(5.89)\end{array}$ & \\
\hline ATI*BLOCK $* I_{\text {lowlev }}$ & & & & & & $\begin{array}{c}0.24 \\
(8.70)\end{array}$ & \\
\hline ATI*BLOCK $* \mathbf{I}_{\text {large, highlev }}$ & & & & & & & $\begin{array}{c}0.41 \\
(14.51)\end{array}$ \\
\hline ATI*BLOCK* $\mathbf{I}_{\text {large, lowlev }}$ & & & & & & & $\begin{array}{c}\mathbf{0 . 3 9} \\
(\mathbf{1 2 . 5 3})\end{array}$ \\
\hline ATI*BLOCK* $\mathbf{I}_{\text {small, highlev }}$ & & & & & & & $\begin{array}{c}-0.45 \\
(-17.84)\end{array}$ \\
\hline ATI*BLOCK $* I_{\text {small, lowlev }}$ & & & & & & & $\begin{array}{c}-0.33 \\
(-9.94)\end{array}$ \\
\hline LEVERAGE & $\begin{array}{c}-1.61 \\
(-14.55)\end{array}$ & $\begin{array}{c}-1.76 \\
(-15.56)\end{array}$ & $\begin{array}{c}-1.69 \\
(-15.17)\end{array}$ & $\begin{array}{c}-1.64 \\
(-14.54)\end{array}$ & $\begin{array}{c}-1.67 \\
(-14.32)\end{array}$ & $\begin{array}{c}-1.64 \\
(-16.48)\end{array}$ & $\begin{array}{c}-1.72 \\
(-16.53)\end{array}$ \\
\hline LN ASSETS & $\begin{array}{c}0.19 \\
(9.23)\end{array}$ & $\begin{array}{c}0.23 \\
(10.39)\end{array}$ & $\begin{array}{c}0.22 \\
(10.39)\end{array}$ & $\begin{array}{c}0.18 \\
(7.78)\end{array}$ & $\begin{array}{c}0.00 \\
(-0.21)\end{array}$ & $\begin{array}{c}0.18 \\
(7.91)\end{array}$ & $\begin{array}{c}0.05 \\
(2.27)\end{array}$ \\
\hline TTM & $\begin{array}{c}0.01 \\
(11.04)\end{array}$ & $\begin{array}{c}0.01 \\
(13.05)\end{array}$ & $\begin{array}{c}0.01 \\
(11.13)\end{array}$ & $\begin{array}{c}0.01 \\
(13.38)\end{array}$ & $\begin{array}{c}0.01 \\
(15.53)\end{array}$ & $\begin{array}{c}0.01 \\
(12.56)\end{array}$ & $\begin{array}{c}0.01 \\
(14.10)\end{array}$ \\
\hline SENIOR & $\begin{array}{c}0.36 \\
(5.01)\end{array}$ & $\begin{array}{c}0.37 \\
(4.51)\end{array}$ & $\begin{array}{c}0.33 \\
(4.61)\end{array}$ & $\begin{array}{c}0.38 \\
(4.93)\end{array}$ & $\begin{array}{c}0.30 \\
(4.49)\end{array}$ & $\begin{array}{c}0.40 \\
(5.02)\end{array}$ & $\begin{array}{c}0.31 \\
(3.92)\end{array}$ \\
\hline SENIOR SECURED & $\begin{array}{c}0.43 \\
(5.23)\end{array}$ & $\begin{array}{c}0.51 \\
(6.07)\end{array}$ & $\begin{array}{c}0.50 \\
(6.39)\end{array}$ & $\begin{array}{c}0.40 \\
(4.85)\end{array}$ & $\begin{array}{c}0.22 \\
(3.32)\end{array}$ & $\begin{array}{c}0.45 \\
(5.49)\end{array}$ & $\begin{array}{c}0.27 \\
(3.59)\end{array}$ \\
\hline $\mathbf{C}$ & $\begin{array}{c}-0.32 \\
(-9.02)\end{array}$ & $\begin{array}{c}-0.31 \\
(-9.16)\end{array}$ & $\begin{array}{c}-0.32 \\
(-8.67)\end{array}$ & $\begin{array}{c}-0.33 \\
(-9.30)\end{array}$ & $\begin{array}{c}-0.28 \\
(-10.90)\end{array}$ & $\begin{array}{c}-0.33 \\
(-9.19)\end{array}$ & $\begin{array}{c}-0.28 \\
(-9.98)\end{array}$ \\
\hline Model $\chi^{2}$ & 3536.94 & 3596.43 & 3558.47 & 3513.74 & 3283.96 & 3464.54 & 3297.80 \\
\hline
\end{tabular}




\section{Table 6. Effect of shareholder control on ratings: EXT}

Reported are the results from an ordered probit model to relate corporate bond ratings to the governance variables EXT and BLOCK (see Table 1 for a description), a constant and a set of controls (see Table 5). Only the results for the governance variables are reported. Dummies indicating the 33\% of largest/smallest firms are $\mathrm{I}_{\text {large }}$ and $\mathrm{I}_{\text {small }}$, those indicating the $33 \%$ of firms with highest and lowest leverage are $\mathrm{I}_{\text {highlev }}$ and $\mathrm{I}_{\text {lowlev. }}$ We first estimate the probit regressions across bonds per quarter and the report the time series average of the coefficients and their t-statistics between parentheses. We use a 7-way classification representing $\mathrm{S} \& \mathrm{P}$ ratings (closest to) AAA, AA, BBB, BB, B, CCC, and lower. Our sample includes an average of 1,839 bonds per year from 1990 to 1997, with on average 4.3 corporate bond issues per firm.

\begin{tabular}{|c|c|c|c|c|c|c|c|}
\hline MODEL & 1 & 2 & 3 & 4 & 5 & 6 & 7 \\
\hline BLOCK & $\begin{array}{c}-0.48 \\
(-18.44)\end{array}$ & & & $\begin{array}{c}0.51 \\
(5.06)\end{array}$ & $\begin{array}{c}0.94 \\
(7.35)\end{array}$ & $\begin{array}{c}0.47 \\
(4.83)\end{array}$ & $\begin{array}{l}0.75 \\
(6.65)\end{array}$ \\
\hline EXT & & $\begin{array}{c}\text { 0.06 } \\
(\mathbf{1 8 . 9 0})\end{array}$ & & $\begin{array}{c}\mathbf{0 . 1 0} \\
(21.36)\end{array}$ & $\begin{array}{c}0.11 \\
(20.18)\end{array}$ & $\begin{array}{c}0.10 \\
(20.86)\end{array}$ & $\begin{array}{c}0.11 \\
(20.74)\end{array}$ \\
\hline EXT*BLOCK & & & $\begin{array}{c}-0.03 \\
(-15.65)\end{array}$ & $\begin{array}{c}-0.07 \\
(-8.91)\end{array}$ & $\begin{array}{c}-0.11 \\
(-11.63)\end{array}$ & $\begin{array}{c}-0.09 \\
(-11.27)\end{array}$ & $\begin{array}{c}-0.10 \\
(-11.58)\end{array}$ \\
\hline EXT*BLOCK* $\mathbf{I}_{\text {large }}$ & & & & & $\begin{array}{c}0.05 \\
(24.19)\end{array}$ & & \\
\hline EXT*BLOCK*I Ismall & & & & & $\begin{array}{c}-0.07 \\
(-24.33)\end{array}$ & & \\
\hline EXT*BLOCK* $\mathbf{I}_{\text {highlev }}$ & & & & & & $\begin{array}{c}0.03 \\
(6.30)\end{array}$ & \\
\hline EXT*BLOCK*I I Iowlev & & & & & & $\begin{array}{c}\text { 0.04 } \\
(7.96)\end{array}$ & \\
\hline EXT*BLOCK* $\mathbf{I}_{\text {large, highlev }}$ & & & & & & & $\begin{array}{c}\text { O.06 } \\
(\mathbf{1 2 . 0 0 )}\end{array}$ \\
\hline EXT*BLOCK* $\mathbf{I}_{\text {large, lowlev }}$ & & & & & & & $\begin{array}{c}\mathbf{0 . 0 7} \\
(\mathbf{1 3 . 4 0 )}\end{array}$ \\
\hline EXT*BLOCK* $\mathbf{I}_{\text {small, highlev }}$ & & & & & & & $\begin{array}{c}-0.08 \\
(-18.61)\end{array}$ \\
\hline EXT*BLOCK*I $\mathbf{I}_{\text {small, lowlev }}$ & & & & & & & $\begin{array}{c}-0.05 \\
(-9.22)\end{array}$ \\
\hline
\end{tabular}




\section{Table 7. Abnormal returns of long-short bond portfolios}

Reported are the annualized mean excess returns and the annualized abnormal return of several long-short bond portfolios. We use the Elton, Gruber and Blake (1995) four-factor bond-pricing model to calculate abnormal returns. In Panel A (B), the portfolios buy all bonds of firms with and short bonds of firms without a blockholder, either unconditional or conditional on the level of ATI (EXT). Here, the levels of ATI and EXT refer to the levels of their categories, not their precise respective values. Further, in Panel C (D), the portfolios buy all bonds of firms with the highest category of ATI (EXT) and short bonds of firms in the lowest ATI (EXT) category, either unconditional or conditional on the existence $(\mathrm{BLOCK}=1)$ or the absence (BLOCK = 1) of a blockholder. Both equally weighted and value-weighted portfolios are used.

\section{EW long-short portfolios}

VW long-short portfolios

Panel A: Long blockholder, short no blockholder, using ATI

\begin{tabular}{cccccccc} 
Mean & Alpha & t-stat & ATI & Mean & Alpha & $t$-stat & ATI \\
\hline $\mathbf{1 . 1 9}$ & $\mathbf{1 . 2 5}$ & $\mathbf{3 . 4 4}$ & All & $\mathbf{1 . 1 0}$ & $\mathbf{0 . 6 7}$ & $\mathbf{2 . 7 4}$ & All \\
& & & & & & & \\
$\mathbf{0 . 8 1}$ & $\mathbf{0 . 8 2}$ & 1.31 & 1 & 0.57 & 0.55 & 1.33 & 1 \\
$\mathbf{1 . 1 5}$ & $\mathbf{1 . 3 6}$ & $\mathbf{3 . 2 5}$ & $\mathbf{2}$ & 0.94 & 0.43 & 1.41 & 2 \\
$\mathbf{1 . 4 9}$ & $\mathbf{1 . 3 4}$ & $\mathbf{2 . 3 5}$ & $\mathbf{3}$ & $\mathbf{1 . 6 5}$ & $\mathbf{0 . 9 1}$ & $\mathbf{1 . 9 9}$ & $\mathbf{3}$
\end{tabular}

Panel B: Long blockholder, short no blockholder, using EXT

\begin{tabular}{cccccccc} 
Mean & Alpha & $t$-stat & EXT & Mean & Alpha & $t$-stat & EXT \\
\hline 0.65 & 0.77 & 1.67 & 1 & $\mathbf{1 . 2 3}$ & $\mathbf{0 . 8 4}$ & $\mathbf{2 . 2 4}$ & $\mathbf{1}$ \\
$\mathbf{1 . 0 5}$ & $\mathbf{1 . 2 7}$ & $\mathbf{2 . 6 6}$ & $\mathbf{2}$ & 0.70 & 0.55 & 1.45 & 2 \\
$\mathbf{1 . 8 0}$ & $\mathbf{1 . 6 3}$ & $\mathbf{2 . 9 4}$ & $\mathbf{3}$ & 1.37 & 0.69 & 1.56 & 3
\end{tabular}

Panel C: Long high ATI, short low ATI

\begin{tabular}{cccccccc} 
Mean & Alpha & $t$-stat & BLOCK & Mean & Alpha & $t$-stat & BLOCK \\
\hline 0.39 & -0.01 & -0.02 & All & -0.31 & -0.35 & -1.24 & All \\
& & & & & & & \\
0.05 & -0.22 & -0.35 & 0 & -0.83 & -0.51 & -1.60 & 0 \\
0.73 & 0.30 & 0.51 & 1 & 0.24 & -0.15 & -0.29 & 1
\end{tabular}

Panel D: Long high EXT, short low EXT

\begin{tabular}{cccccccc} 
Mean & Alpha & t-stat & BLOCK & Mean & Alpha & $t$-stat & BLOCK \\
\hline 0.04 & 0.27 & 0.57 & 0 & -0.10 & 0.04 & 0.13 & 0 \\
$\mathbf{1 . 1 9}$ & $\mathbf{1 . 1 3}$ & $\mathbf{2 . 3 2}$ & $\mathbf{1}$ & 0.04 & -0.12 & -0.21 & 1
\end{tabular}




\section{Table 8. Regressing bond alphas on size, leverage, levels of ATI, EXT and BLOCK}

Reported are the results for the weighted-least-squares regressions of annualized bond alphas on sizeleverage dummies (in panel A), and on the level of the governance variables ATI, EXT and BLOCK (denoted by 'BL') conditional on size and leverage (in panel B). For a description of these governance variables, see Table 1 . The dummies indicating the $33 \%$ of largest/medium/smallest size firms are $\mathrm{I}_{\text {large }}, \mathrm{I}_{\text {med }}$ and $\mathrm{I}_{\text {small }}$, and the dummies indicating the $67 \%$ and $33 \%$ of firms with lowest and highest leverage are $\mathrm{I}_{\text {low }}$ and $\mathrm{I}_{\text {high. }}$. The levels of ATI and EXT refer to the levels of their categories, not their precise respective values. We use the Elton, Gruber and Blake (1995) four-factor bond-pricing model to calculate alphas. The alphas are those of the 54 portfolios of bond issues created by $3 \times 2 \times 3 \times 3$ sorts on ATI (or EXT) x BLOCK $x$ SIZE x LEV. All portfolio returns are equally-weighted. Finally, we report the regression coefficients plus their t-statistics between parentheses, and the $\mathrm{R}^{2}$ and the adjusted $\mathrm{R}^{2}$ are given for each regression as well.

\section{Panel A - Mispricing}

Using ATI x BLOCK x SIZE x LEV sorted bond portfolios

\begin{tabular}{ccccccc}
$I_{\text {small,low }}$ & $I_{\text {med,low }}$ & $I_{\text {large, low }}$ & $I_{\text {small,high }}$ & $I_{\text {med,high }}$ & $I_{\text {large, high }}$ & $R 2$ \\
\hline $\mathbf{0 . 7 9}$ & 0.47 & 0.14 & $\mathbf{2 . 3 4}$ & 0.20 & 0.25 & adj. R2 \\
$(\mathbf{2 . 2 0})$ & $(1.54)$ & $(0.53)$ & $\mathbf{( 2 . 3 3 )}$ & $(0.66)$ & $(0.95)$ & $15.97 \%$
\end{tabular}

Using EXT x BLOCK x SIZE x LEV sorted bond portfolios

\begin{tabular}{ccccccc}
$I_{\text {small,low }}$ & $I_{\text {med,low }}$ & $I_{\text {large, low }}$ & $I_{\text {small,high }}$ & $I_{\text {med,high }}$ & $I_{\text {large,high }}$ & $R 2$ \\
\hline $\mathbf{0 . 9 2}$ & 0.83 & 0.33 & $\mathbf{5 . 1 8}$ & 0.66 & 0.68 & adj. R2 \\
$(\mathbf{3 . 0 5})$ & $(3.85)$ & $(1.82)$ & $\mathbf{( 6 . 8 9 )}$ & $(2.49)$ & $(2.66)$ & $36.03 \%$
\end{tabular}

\section{Panel B - The effect of Size}

\section{Using ATI x BLOCK x SIZE x LEV sorted bond portfolios}

\begin{tabular}{|c|c|c|c|c|c|c|}
\hline$A T I^{*} I_{\text {small }}$ & $A T I * I_{m e d}$ & $A T I * I_{\text {large }}$ & $I_{\text {small, low }}$ & $I_{\text {small,high }}$ & $R 2$ & adj. $R 2$ \\
\hline 0.77 & 0.16 & 0.04 & -0.49 & 1.07 & $26.44 \%$ & $18.78 \%$ \\
\hline (2.98) & (2.10) & $(0.56)$ & $(-1.11)$ & (1.06) & & \\
\hline$B L * I_{\text {small }}$ & $B L * I_{\text {med }}$ & $B L * I_{\text {large }}$ & $I_{\text {small, low }}$ & $I_{\text {small,high }}$ & $R 2$ & adj. $R 2$ \\
\hline $\begin{array}{c}1.35 \\
(5.08)\end{array}$ & $\begin{array}{c}0.25 \\
(2.08)\end{array}$ & $\begin{array}{c}0.02 \\
(0.19)\end{array}$ & $\begin{array}{c}-1.25 \\
(-3.07)\end{array}$ & $\begin{array}{c}1.45 \\
(1.64)\end{array}$ & $37.24 \%$ & $30.71 \%$ \\
\hline
\end{tabular}

\section{Using EXT x BLOCK x SIZE x LEV sorted bond portfolios}

\begin{tabular}{ccccccc}
$E X T^{*} I_{\text {small }}$ & $E X T^{*} I_{\text {med }}$ & $E X T^{*} I_{\text {large }}$ & $I_{\text {small, low }}$ & $I_{\text {small,high }}$ & $R 2$ & adj. $R 2$ \\
\hline $\mathbf{1 . 0 8}$ & 0.08 & -0.08 & -1.28 & 3.25 & $45.65 \%$ & $39.99 \%$ \\
$(\mathbf{3 . 6 7})$ & $(1.15)$ & $(-1.28)$ & $(-2.70$ & $4.07)$ & \\
& & & $I_{\text {small, low }}$ & $I_{\text {small,high }}$ & $R 2$ & adj. $R 2$ \\
$B L * I_{\text {small }}$ & $B L * I_{\text {med }}$ & $B L * I_{\text {large }}$ & -0.55 & 3.05 & $42.49 \%$ & $36.50 \%$ \\
$\mathbf{0 . 8 9}$ & 0.10 & 0.04 & $(-1.32$ & $3.51)$ &
\end{tabular}




\section{Table 9. Regressing bond alphas on the Minimum(ATI/EXT , BLOCK)}

Reported are the results for the weighted-least-squares regressions of annualized bond alphas on the Minimum of the level of ATI and BLOCK (in Panel A) or of EXT and BLOCK (in Panel B), conditional on size and leverage. For a description of these governance variables, see Table 1 . The dummies indicating the $33 \%$ of largest/medium/smallest size firms are $\mathrm{I}_{\text {large }}, \mathrm{I}_{\text {med }}$ and $\mathrm{I}_{\text {small }}$, and the dummies indicating the $67 \%$ and 33\% of firms with lowest and highest leverage are $\mathrm{I}_{\text {low }}$ and $\mathrm{I}_{\text {high. }}$. The levels of ATI and EXT refer to the levels of their categories, not their precise respective values. We use the Elton, Gruber and Blake (1995) four-factor bond-pricing model to calculate alphas. The alphas are those of the 54 portfolios of bond issues created by 3 x 2 x 3 x 3 sorts on ATI (or EXT) x BLOCK x SIZE x LEV. All portfolio returns are equallyweighted. Finally, we report the regression coefficients plus their t-statistics between parentheses, and the $R^{2}$ and the adjusted $R^{2}$ are given for each regression as well.

\section{Panel A: Using ATI x BLOCK x SIZE x LEV sorted bond portfolios}

\begin{tabular}{|c|c|c|c|c|c|c|c|c|c|}
\hline Min $* I_{\text {small, low }}$ & $\operatorname{Min} * I_{\text {med,low }}$ & $\operatorname{Min}^{*} I_{\text {large, low }}$ & Min $* I_{\text {small,high }}$ & Min $* I_{m e d, h i g h}$ & Min $* I_{\text {large,high }}$ & $I_{\text {small,low }}$ & $I_{\text {small,high }}$ & $R 2$ & adj. $R 2$ \\
\hline (3.15) & (1.73) & $(-0.82)$ & $(0.61)$ & $(0.28)$ & $(-0.69)$ & & $(0.65)$ & & \\
\hline 1.33 & 0.18 & -0.13 & 1.09 & 0.16 & -0.07 & -1.03 & 1.88 & $37.68 \%$ & $26.60 \%$ \\
\hline (3.99) & (1.41) & $(-1.21)$ & $(0.89)$ & (1.00) & $(-0.54)$ & $(-2.51)$ & (0.89) & & \\
\hline
\end{tabular}

Panel B: Using EXT x BLOCK x SIZE x LEV sorted bond portfolios

\begin{tabular}{|c|c|c|c|c|c|c|c|c|c|}
\hline Min $* I_{\text {small, low }}$ & $\operatorname{Min} * I_{\text {med,low }}$ & $\operatorname{Min}^{*} I_{\text {large, low }}$ & Min $* I_{\text {small,high }}$ & $\operatorname{Min} * I_{m e d, h i g h}$ & Min ${ }^{\prime} I_{\text {large, high }}$ & $I_{\text {small, low }}$ & $I_{\text {small,high }}$ & $R 2$ & adj. $R 2$ \\
\hline 0.62 & 0.33 & -0.13 & 2.97 & 0.22 & 0.09 & & 0.74 & $45.04 \%$ & $36.68 \%$ \\
\hline (2.84) & (3.17) & $(-1.51)$ & (2.30) & (1.66) & $(0.90)$ & & $(0.40)$ & & \\
\hline
\end{tabular}

\begin{tabular}{|c|c|c|c|c|c|c|c|c|c|}
\hline Min $* I_{\text {small, low }}$ & $\operatorname{Min} * I_{m e d, l o w}$ & $\operatorname{Min}^{*} I_{\text {large, low }}$ & Min $* I_{\text {small,high }}$ & $\operatorname{Min} * I_{m e d, h i g h}$ & Min $* I_{\text {large,high }}$ & $I_{\text {small, low }}$ & $I_{\text {small,high }}$ & $R 2$ & adj. $R 2$ \\
\hline 1.38 & 0.22 & -0.22 & 3.20 & 0.21 & 0.02 & -1.09 & 0.86 & $49.02 \%$ & $39.95 \%$ \\
\hline (3.94) & (2.13) & $(-2.53)$ & (2.64) & (1.68) & $(0.23)$ & $(-2.67)$ & $(0.50)$ & & \\
\hline
\end{tabular}




\section{Table 10. The Poison Put Covenant: Effect of shareholder control on bond spreads}

Reported are the pooled OLS regression coefficients plus their t-statistics in parentheses of regressing monthly corporate bond spreads on the governance variables ATI and BLOCK, both for the full sample as well as for the subset of bonds issued with a poison put. See Table 1 for a description of ATI and BLOCK. The regressions also include a constant, a set of controls (see Table 3, panel A) and fixed issuer effects, but only the coefficients of the governance variables are reported. Dummies indicating the $33 \%$ of largest/smallest firms are $\mathrm{I}_{\text {large }}$ and $\mathrm{I}_{\text {small }}$, those indicating the $33 \%$ of firms with highest and lowest leverage are $\mathrm{I}_{\text {highlev }}$ and $\mathrm{I}_{\text {lowlev. }}$ Our full sample includes an average of 1,839 bonds per year from 1990 to 1997, with on average 4.3 corporate bond issues per firm. Our sample of bond issues with poison puts includes an average of 237 bonds per year from 1990 to 1997, with on average 1.73 corporate bond issues per firm.

ATI + fixed issuer effect

\begin{tabular}{|c|c|c|c|c|}
\hline & \multicolumn{4}{|c|}{ ATI + fixed issuer effect } \\
\hline & \multicolumn{2}{|c|}{ MODEL 4} & \multicolumn{2}{|c|}{ MODEL 7} \\
\hline & Full Sample & Poison Put & Full Sample & Poison Put \\
\hline \multirow[t]{2}{*}{ BLOCK } & -0.15 & -0.15 & -0.08 & -0.10 \\
\hline & $(-3.17)$ & $(-0.67)$ & $(-0.77)$ & $(-0.45)$ \\
\hline \multirow[t]{2}{*}{ ATI } & 0.03 & 0.18 & 0.02 & 0.19 \\
\hline & $(1.10)$ & $(1.35)$ & $(1.80)$ & $(1.45)$ \\
\hline \multirow[t]{2}{*}{ ATI*BLOCK } & 0.08 & 0.04 & 0.01 & -0.04 \\
\hline & (3.87) & $(0.36)$ & $(1.09)$ & $(-0.37)$ \\
\hline \multirow[t]{2}{*}{ ATI*BLOCK*I $\mathbf{I}_{\text {large, highlev }}$} & & & -0.01 & 0.06 \\
\hline & & & $(-3.39)$ & $(0.63)$ \\
\hline \multirow[t]{2}{*}{ ATI*BLOCK*I I Iarge, lowlev } & & & -0.00 & 0.04 \\
\hline & & & $(-0.49)$ & $(0.31)$ \\
\hline \multirow[t]{2}{*}{ ATI*BLOCK $* I_{\text {small, highlev }}$} & & & 0.01 & 0.17 \\
\hline & & & $(2.58)$ & (3.15) \\
\hline \multirow[t]{2}{*}{ ATI*BLOCK* $\mathbf{I}_{\text {small, lowlev }}$} & & & 0.02 & 0.07 \\
\hline & & & (3.79) & $(0.77)$ \\
\hline Adjusted R2 & $7.51 \%$ & $7.08 \%$ & $7.56 \%$ & $7.33 \%$ \\
\hline
\end{tabular}

